\title{
Honey from the Rock: Principles of integral mission learnt from beekeeping development in the uMfolozi area of South Africa
}

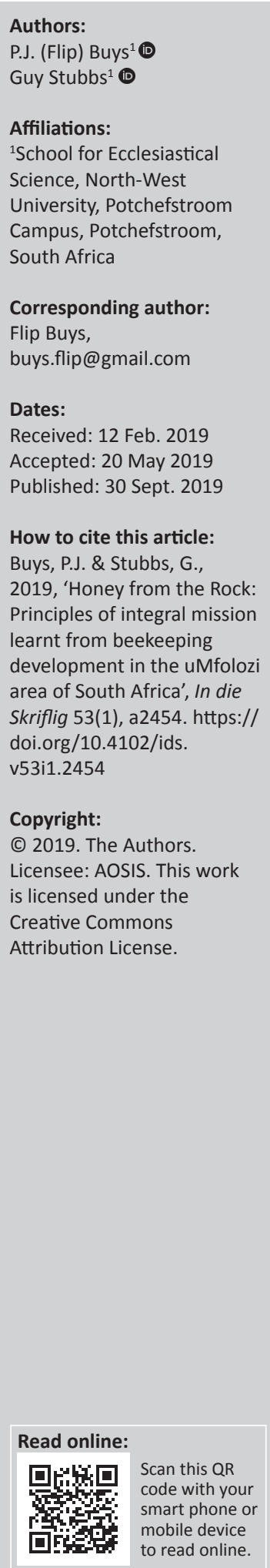

In many parts of South Africa, mission work is being done in communities living in desperate poverty. There is a great need for integral mission, bringing word and deed together in the proclamation of the gospel to equip Christians to have hope and engage in the fullness of community life to become responsible Christian stewards in the midst of a broken world. This article evaluates a relatively successful poverty alleviation project as an example of an integral mission project that the researcher initiated in 2016 in Northern KwaZulu-Natal, South Africa. In order to analyse the context, measure, manage and share the progress of the project, an app called 'The Impact app' was developed and used to collect data. The empirical research in this article comes from data collected over a period of four years primarily from this app and other sources. The main system structure that the researcher used for this integral project is called 'Franchising as Mission'. It takes the best attributes of primary and secondary coops yet, enables governance and a fair share in the value chain. Poverty alleviation and gospel proclamation have been integrated in the whole project. Therefore, this entire project was regarded as Evangelical Christian Integral Mission as described in the Lausanne Covenant and elaborated on by Melba Padilla Maggay. It is these three core attributes that have led to a $92 \%$ higher uptake to that envisaged (Figure 14). This article hopes to point out what integral mission looks like in practice.

Keywords: Honey; beekeeping; integral mission; Umfolozi Municipality of South Africa; poverty alleviation; franchising; Asset-Based Community Development (ABCD).

\section{Introduction: Biblical perspective on the value of beekeeping}

There are 68 references to bees, honey and honeycomb in the Bible (Root 1975:66-69). Honey is regarded as essential and delicious food that nourishes and sustains life. 'Honey from the rock' is specifically used in Deuteronomy 32:13 and Psalm 81:16 as part of a figure of speech suggesting the strength and triumph of God's people as a result of Yahweh's loving care in leading them during their travel through the desert resulting in his abundant provision of sustenance in the land of Canaan. There was the produce of field, honey from the rock and oil from the flint rock (Merrill 1994:415). The Hebrew word צוּר for honey is frequently mentioned metaphorically as a type of the Divine blessing and is distinguished as something extraordinary and preternatural by this hyperbolical expression (Lange et al. 2008:453). Philo compares the divine wisdom to honey (Kittel, Bromiley \& Friedrich 1985:577). Honey ${ }^{1}$, as the 'chief of sweet things', has inspired many figurative allusions (e.g. Ps 19:9-10; Pr 5:3; 24:13-14; Ezk 3:2-3; Rv 10:9; cf. also Butler et al. 2003). Wisdom about Christ's love leads to faith, temporal and eternal hope, and this, in turn, results in a sharing and replication of love. This all flows from God as Father, Son and Holy Spirit - our Rock.

Many poor rural families in South Africa often live with excellent prime honeybee flora resources on their doorstep that they do not benefit from. Realising this, the researcher launched on a journey of exploration to see if he could find a way of helping the families benefit from the resources and from their God-given talents, and transform their lives in the process from dependency to dignity. Being a missionary at heart, the vision of the researcher was to combine gospel proclamation with poverty alleviation as described by Maggay (2007:7-12) and Wright (2015:22-30; cf. also The Cape Town Commitment 1.7.c). This was then practically done through helping people to develop skills of honey beekeeping. ${ }^{2}$

1.During Bible times, honey appeared in three forms: honey deposited from wild bees (Dt 32:13); honey from domesticated bees (one of the products 'of the field'-2 Chr 31:5); and a syrup made from dates and grape juice (2 Ki 18:32; Gary 2003:779).

2.Due to the delimitation of article length, the theological and missional foundations of the projects are limited in this article. The authors, however, follow the views described in Buys (2013): 'A missional response to poverty and social justice', in particular, the definitions mentioned on pages 16, 17 and 19 and references to Bruwer (1994) and Chester (2004; 2004a and 2002). The explanations of Myers (2011:60ff) on the complexity of understanding the root causes of poverty were also kept in mind in developing this project. 
The researcher started with the idea of using beekeeping as a poverty alleviation activity in 2007 in a different part of South Africa. He made many mistakes and wasted lots of development funding. However, learning from his mistakes, the researcher developed a model which, in the last three years, has been successful. In this article, the researcher highlights lessons learnt as possible methodologies for those setting out to alleviate poverty as a vital aspect of integral mission.

The model is about enabling people to realise that, through God's transforming grace in Christ, they are capable to change their own lives. In this way, members experience a foretaste of already participating in God's new creation (Wright 2008) as explained in 2 Peter (Henry 1991). The Holy Spirit empowers Christians to live righteously, despite opposition, resulting in fruitful productive lives. In secular circles, the method of self-transformation is sometimes called Asset-Based Community Development (ABCD) (discussed in more detail further on in the article).

Social and micro-franchising (discussed in more detail further on in the article) provides biblical based replication, social cohesion and support. Microfinance (discussed in more detail further on in the article), starting with saving, borrowing and lending in a structured group; access to market and sharing value chain profits can be one example of the kind of love spoken about in 1 Thessalonians 5:11 (Henry 1991), that enables sustainability.

The use of technology (and available resources) has been used to develop a system that enables governance, management (Appendix 5), measurement, knowledge of progress and economics (Appendix 6), bearing in mind that, as David prays in 1 Chronicles 29:11-12 (Henry 1991), all is in God's hands, and when he blesses us, we are to be a blessing to others.

In order to manage, measure and evaluate the project, the researcher worked with SaveAct (2018) who oversaw savings activities, and developed an AppSheet (2018) and an Android (2018) based measurement tool called 'The Impact app'. Charisma Technology, a systems solution company (Charismatech 2018) are helping the researcher to refine the app and develop dashboards that can be used by facilitators, management and stakeholders to run the African Honey Bee (AHB) project. Most of the data referred to in this article was collected by this app.

\section{Problem statement}

Murray (2004) expresses the opinion that the root cause of poverty is sin. He points out that poverty comes from being sinful, for example laziness, or suffering because of the sin of others or the suffering the consequences of the fall, such as natural disasters. Myers suggests that it is sin that has caused broken relationships with God, the self, each other and the community (Myers 2011:47-103). Table 1 is helpful to provide a biblical overview of the complexities of poverty (Myers 2011).

In 2007, the world began to become aware of a global decline in bee populations resulting in less honey production (Allsopp 2017). In recent years, there have been interesting statistics, for example that more honey has been exported from China than produced (Kennedy 2018). The researcher realised that many of South Africa's poor rural communities were living with prime beekeeping resources (bee plants) on their doorsteps, that they were not benefitting from. Not only did they have natural resources for beekeeping, but they had all kinds of resources and God-given talents that they were not using or benefitting from, largely (as will be seen in the empirical study) because of a lack of self-worth which negatively affected their wellbeing.

\section{The African Honey Bee project in Umfolozi}

This project started in March of 2016 (the middle of the honey flow - see Figure 1). The community areas of Sokhulu and Mbonambi were selected as prime areas because of their profusion of Eucalyptus grandis subspecies (an excellent bee plant - see Figures 6, 7 and 8).

Participants were invited through local networks to attend a workshop where they were taught how to make beekeeping equipment from materials available to them in their own homes, for example old jeans for gloves and old tins for smokers.

\begin{tabular}{|c|c|c|c|c|c|}
\hline View of the poor & Theological frame & Key biblical texts & Expressions & Why the poor are poor & Christian response \\
\hline Poor made in the image of God & - Creation & - Genesis 1-2 & $\begin{array}{l}\text { - Poor as creative, poor as a work of } \\
\text { art. } \\
\text { - See God's hidden glory. }\end{array}$ & $\begin{array}{l}\text { - The poor lack skills, } \\
\text { knowledge, and } \\
\text { opportunity. }\end{array}$ & $\begin{array}{l}\text { Enable the poor to be fruitful } \\
\text { and productive. }\end{array}$ \\
\hline Poor as people in rebellion & - Fall & $\begin{array}{l}\text { - Genesis } 3 \\
\text { - Proverbs }\end{array}$ & $\begin{array}{l}\text { - Poor as lazy, poor makes bad choices, } \\
\text { God helps those who help } \\
\text { themselves. }\end{array}$ & $\begin{array}{l}\text { - The poor are in rebellion } \\
\text { and their culture keeps } \\
\text { them poor. }\end{array}$ & $\begin{array}{l}\text { Challenge the poor with the } \\
\text { gospel and encourage them to } \\
\text { make better choices. }\end{array}$ \\
\hline Poor as Christ incarnate & - Incarnation & - Gospels & $\begin{array}{l}\text { Christ in the distressing guise of the } \\
\text { poor. } \\
\text { - What you did for the least of these ... }\end{array}$ & - The poor lack love. & $\begin{array}{l}\text { Accompany the poor and } \\
\text { relieve suffering as possible. }\end{array}$ \\
\hline Poor as God's favourites & $\begin{array}{l}\text { - Prophetic } \\
\text { - Eschatological }\end{array}$ & $\begin{array}{l}\text { - Exodus } \\
\text { - Prophets }\end{array}$ & $\begin{array}{l}\text { - Blessed are the poor for theirs will be } \\
\text { the kingdom. } \\
\text { - Liberation theology. }\end{array}$ & $\begin{array}{l}\text { The poor are oppressed } \\
\text { by the non-poor. } \\
\text { - Poverty is structural. }\end{array}$ & $\begin{array}{l}\text { Work for justice. Help the poor } \\
\text { find their voice and place in } \\
\text { the socio-political-economic } \\
\text { system. }\end{array}$ \\
\hline Poor as lost souls & $\begin{array}{l}\text { - Salvation } \\
\text { - Soteriological }\end{array}$ & $\begin{array}{l}\text { - Matthew } 28 \\
\text { - Acts }\end{array}$ & $\begin{array}{l}\text { - The better future lies in eternity. } \\
\text { - Save as many as we can. } \\
\text { - The poor will always be with you. }\end{array}$ & $\begin{array}{l}\text { - The poor are lost from } \\
\text { God and the kingdom is } \\
\text { coming soon. }\end{array}$ & $\begin{array}{l}\text { Proclaim the gospel and } \\
\text { encourage the poor to } \\
\text { respond. }\end{array}$ \\
\hline
\end{tabular}

Source: Myers, B.L., 2011, Walking with the poor: Principles and practices of transformational development, p. 60, Orbis Books, New York 


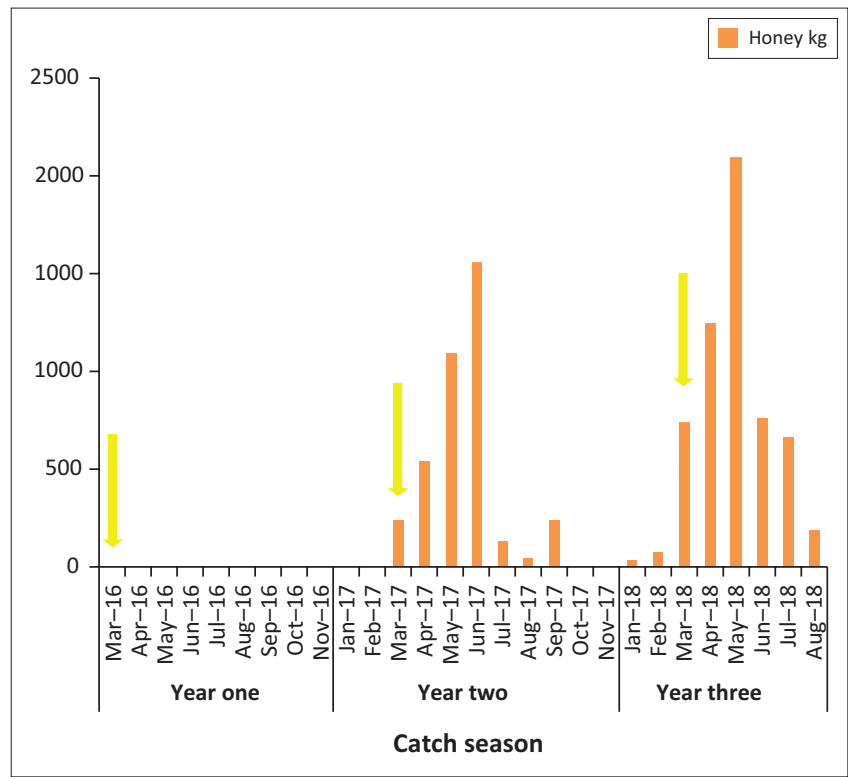

Source: AHB Database, 2018d, 'Honey', ed. by African Honey Bee FIGURE 1: Honey production.

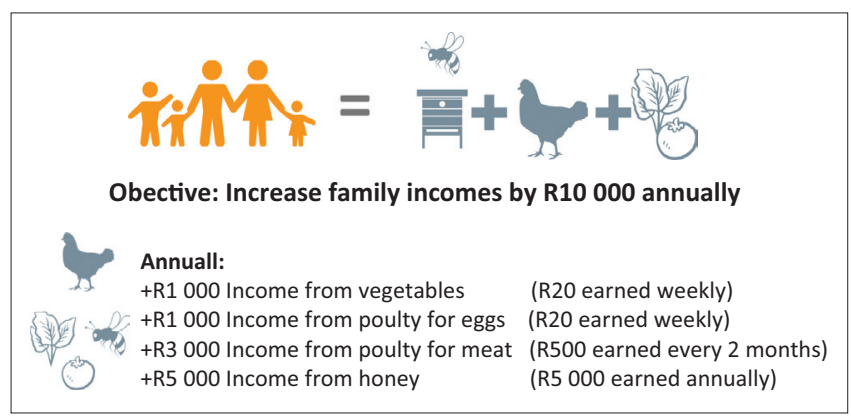

FIGURE 2: Projected income streams.

Those who successfully completed making all the equipment were given a flatpack of materials to build their first hive and signed into the programme. The records in this document only refer to those who were signed up.

Each day of training started with a Bible study using the African Honey Bee Catechism (Reformed Church Tshwane 2016). Bibles were given to those who did not possess one of their own and a catechism was presented to each member.

A month later, the second three-day workshop was held where participants were taught to work as a group and save, borrow and lend as individuals of the group. Monthly saving meetings then followed and before each meeting, training took place.

The next workshop focused on enterprise development skills where members were taught the principles of and the method how to develop a business plan.

The last workshops focused on training four businessesin-a-box businesses: (1) Chicken meat; (2) Chicken eggs; (3) Veggies and fruit; and (4) Honey production. Although beekeeping and the production of honey was central in the project, the researcher specifically did not focus on only honey, because it is an unreliable crop and only provides income once annually (see Figure 1).

The researcher's aim was to double the annual family income from $\pm \mathrm{R} 10000$ earned from social grants to $\pm \mathrm{R} 20000$ by earning an additional \pm R10 000 income from other income generating activities. As can be seen in Figure 2, income needed to be spread out throughout the year and diversified to mitigate cashflow and climate change obstacles. As can be seen by the zero production of honey achieved in 2016 (Figure 1), it is not viable to present beekeeping on its own as a poverty alleviation activity. The researcher therefore introduced other income generating activities to compliment the beekeeping and help break the nutrition poverty cycle. The activities included egg, meat, vegetable and fruit production using climate mitigation methodologies.

\section{Sustainability methodologies used in the project}

Asset-Based Community Development (ABCD) is a methodology for the sustainable development of communities based on their strengths and potentials (McKnight \& Kretzmann 1996).

There are three characteristics of $\mathrm{ABCD}$ that are very relevant for the AHB project:

- To make an inventory of local assets.

- To be internally focused.

- To be relationship driven (De Gruchy $2007^{3}$ ).

This method uses the community's own assets and resources as the basis for development; it empowers the people of the community by encouraging them to utilise what they already possess (Kretzmann \& McKnight 1993:14; Mathews 2013).

De Gruchy (2007) points the following common elements out between $A B C D$ and Christian faith:

- Both recognise that all people are made in the image of God. All people are equal and have innate value, whether they are young, aged, disabled or illiterate.

- Both affirm that all people have a vocation. God has a calling on each person's life that requires them to be agents - and not clients.

- Both recognise that all people have gifts and talents which they use to the glory of God both in the church and in the community.

- Both appreciate the value of labour in making us human. We do not just work to earn money - but it is a fundamental way in which we participate in the activity of God in the world.

- Both believe in the fundamental importance of community. Human beings are constituted by belonging - and seek to solve their problems through communal action.

3.For several years Steve de Gruchy has been writing a regular column for Inside Out, the magazine of the Council for World Mission. His short reflective articles (in PDF the magazine of the Council for World Mission. His short reflective articles (in PDF
format) can be accessed on the website of the University of KwaZulu-Natal (De Gruchy 2007). 
- Both accept that the church and Christians are 'assets' to the community - the light of the world and the salt of the earth.

- Both recognise the importance of changing people's attitudes of mind-sets.

Microfinance is the provision of financial services to poor people, entrepreneurs and small businesses lacking access to bank and related services (Feigenberg, Field \& Pande 2010; Greer \& Smith 2016). The two main mechanisms for the delivery of financial services to such clients were: (1) relationship-based banking for individual entrepreneurs and small businesses; and (2) group-based models where several entrepreneurs come together to apply for loans and other services as a group. Microfinance is a tool to reduce income inequality, allowing citizens from lower socio-economical classes to participate in the economy. Moreover, its involvement has shown to lead to a downward trend in income inequality (Hermes 2014:1021-1034). AHB uses microfinance through establishing savings groups that empower individuals and the community to become selfsustaining.

Micro-franchising is a business model that applies elements and concepts of traditional franchising to small businesses in the developing world (Lehr 2012). It refers to the systemisation and replication of micro-enterprises. Microfranchising is broadly defined as small businesses that can easily be replicated by following proven marketing and operational concepts (Fairbourne, Gibson \& Dyer 2007). AHB used this model to offer its members business-in-abox (honey, vegetables, eggs, meat and fruit production) solutions for generating income.

Social franchising is the application of the principles of commercial franchising to promote social benefit rather than private profit (Montagu 2002:121-130). It is the replication of a method or system that enables poverty alleviation on a large scale. The AHB project was run as a micro-franchise that provides ongoing technical and logistical support and access (and profit share) of the value chain market. With expansion plans, social franchising will be used to replicate the micro-franchise model.

Although the pilot microfranchise model can continue functioning on its own, the model is totally self-sustainable (all levels of franchising are sufficiently incentivised) when it reaches 20000 hives, that is, 4000 beekeeper families with five hives each. Below in Figure 3 revenue distribution is presented in relation to the hierarchy presented in Figure 4. When the incentives are correct, the project becomes selfsustaining and there is no need for third-party funding. Side selling is also reduced. Social cohesion is encouraged and ubuntu $^{4}$ stimulates Christian love. Where ubuntu is ' $\mathrm{I}$ am because we are' (Tutu 2013), it becomes: I am because God is, and so we all are.

4. Ubuntu is a Nguni Bantu term meaning 'humanity'. It is often translated as 'I am because we are', but it is often used in a more philosophical sense to mean 'th belief in a universal bond of sharing that connects all humanity' (Tutu 2013).

\section{uMfolozi}

The municipality is located on the northern coastal plain of KwaZulu-Natal bordering the Indian Ocean towards the east (Figure 5). This compliments its climate and good annual rainfall average. Mtubatuba and Hlabisa big five local municipalities are located towards the northern boundary of the municipality, while Mthonjaneni local municipality borders its west and uMhlathuze municipality borders the south (the home for one of the South Africa's largest harbours Richards Bay Harbour). The N2 traverses the municipality on a north-south direction which leads to iLembe District Municipality and EThekwini Metropolitan Municipality (the home to the second busiest manufacturing hub after Johannesburg).

The uMfolozi local municipality is predominantly rural, as it consists of an impoverished population which depends on traditional forms of living such as subsistence farming, the burning of fossil fuels, sugarcane farming and timber farming to make ends meet. There are very few jobs and, as industries become more and more mechanised, less opportunities force the youth to travel to other areas in search of employment. The researcher chose uMfolozi as an area to develop his beekeeper-based micro-franchise model for integral mission of which poverty alleviation would be a vital aspect because of the vast areas of honey producing Eucalyptus plantations that are grown both commercially and on a small scale by community members in the area - illustrated in Figures 6, 7 and 8 as the dark green areas. This enables families to farm their bees in the safety of their yards, while there is enough bee food (carrying capacity) for beekeeping to be viable.

As can be seen in Figure 6, Eucalyptus trees are scattered among the rural households. Each property is $4-8$ ha and most residents grow Eucalyptus trees that they sell to the large pulp mills in nearby Richards Bay. The most commonly grown Eucalyptus is a grandis subspecie, which is rated as an excellent nectar and pollen producer by the Agricultural Research Council (Johannsmeier 2001:129).

When ranking South African municipalities by population, uMfolozi takes third rank; $99.8 \%$ of the total population is black Africans, while the white population constitutes only $0.8 \%$ of the municipal population and $92.5 \%$ are Zulu speakers. Females are the dominant gender at $52.0 \%$, while males make up $48.0 \%$ of this population. There are 25584 households in the municipality. The average household size in the municipality is 4.6 , and $72.6 \%$ of the households stay in formal dwellings (compared to shacks). Out of the total population of the municipality (122 889), only 17157 are employed. Youth ${ }^{5}$, unemployment in the municipality, is sitting at $50.4 \%$ (almost double of the national poverty rateTrading Economics 2018). Of the total households, 10.5\% have access to piped water inside the dwelling and 5.5\% have flush toilets connected to sewerage (Stats SA 2018).

5.18-36 years old (Stats SA 2015 ). 


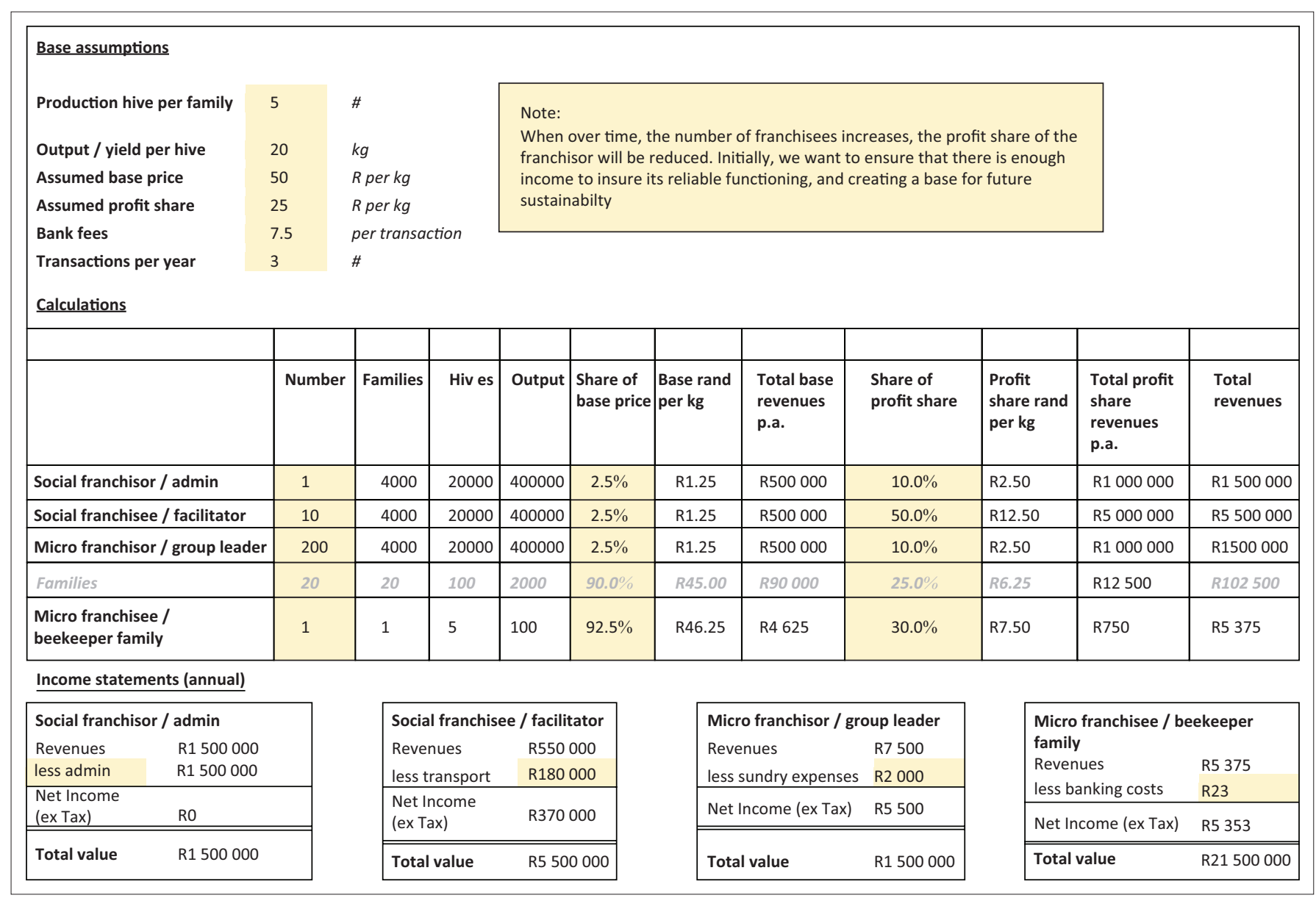

FIGURE 3: Financial illustration of the self-sustainability of the social and micro-franchising model.

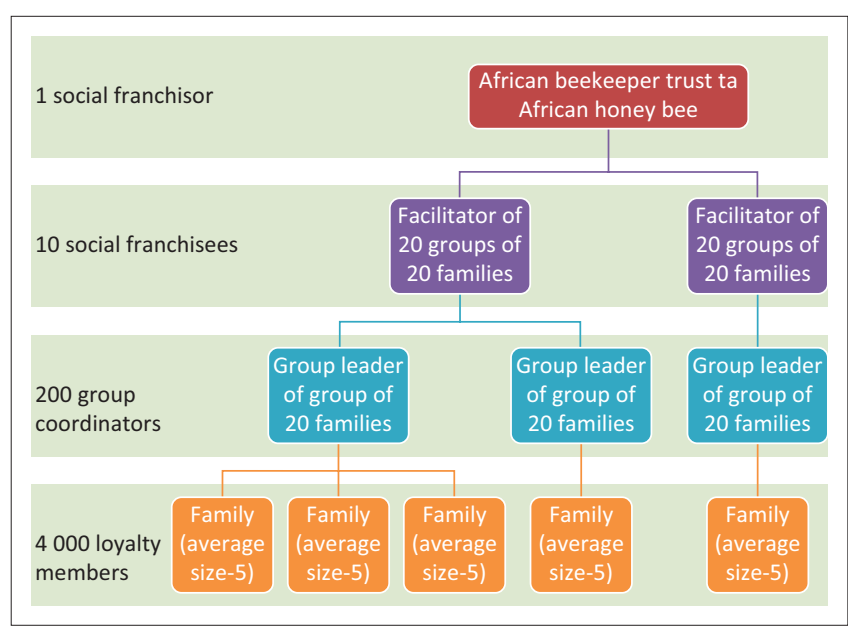

FIGURE 4: Micro- and social franchise model.

According to the Census 2011 results, some primary education for the population, aged 6-13 years, was recorded as being $16.1 \%$. Only $30.3 \%$ of the population in the municipality have matric. The lack of income is rife with $77 \%$ of the inhabitants living on social grants (Stats SA 2017:126). Jobs in the municipality are scarce with the only real employment opportunities being commercial timber, mining, sugarcane, the municipality and tourism. Mechanisation in industry is costing many jobs. An example is the introduction of tree harvesters that each replace 200 people normally required to do the same work (Visser 2017).

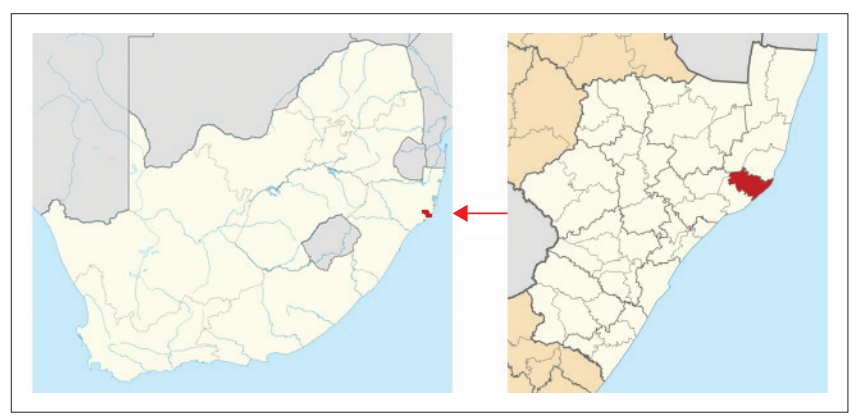

Source: uMfolozi Local Municipality, 2016, uMfolozi Local Municipality website, viewed 29 February 2019, from https://umfolozi.gov.za

FIGURE 5: South Africa with uMfolozi municipality highlighted in red.

According to the Stats SA's General Household Survey in 2015, the vast majority (86\%) of South Africans described their religious affiliation as 'Christian' while a further 5.2\% said that they were not affiliated to any specific religion. More than $5 \%$ of individuals subscribed to religions that were described as 'ancestral, tribal, animist or other traditional African religions' (Stats SA 2015:3, 27-28). Although these figures are exciting, as one can clearly see the knowledge of Jesus spreading throughout South Africa, the gospel message is still not clearly understood by many Christian professing South Africans.

It is interesting to see in Figure 9, that the percentage of people in the AHB project who claim to be Christian (88\%) is greater 


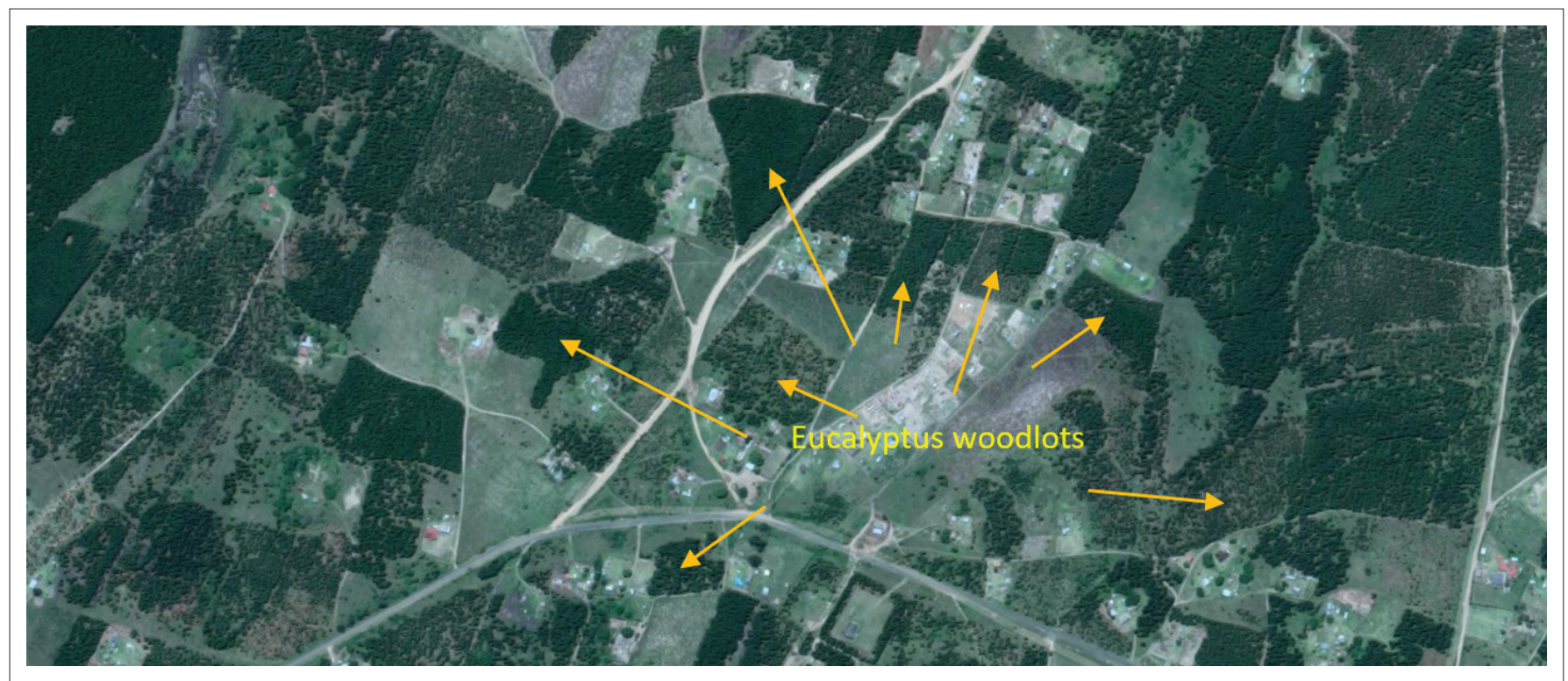

Source: Google Maps, 2018, Google Maps website, viewed 07 May 2019, from www.google.com/maps

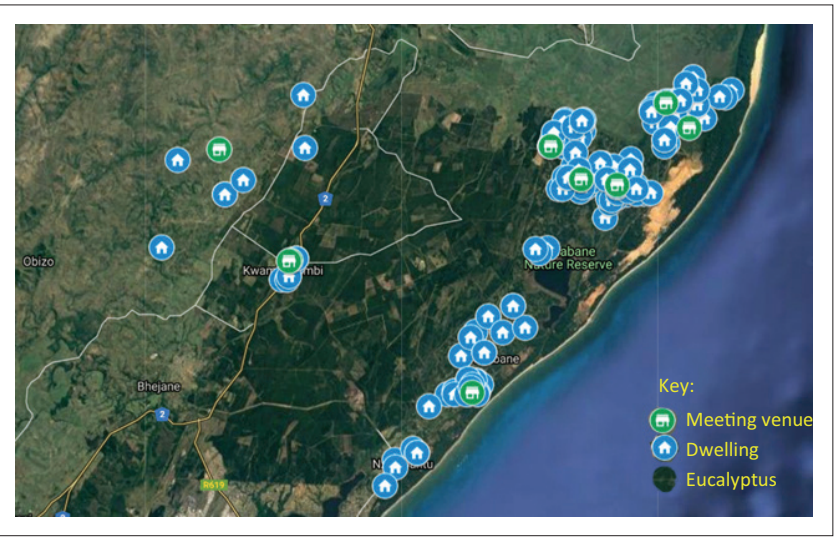

Source: AHB Database, 2018a, 'Age and sex distribution', ed. by African Honey Bee Google Maps, 2018, Google Maps website, viewed 07 May 2019, from www.google. com/maps

FIGURE 7: Sokhulu and Mbonambi with training venues and dwellings.

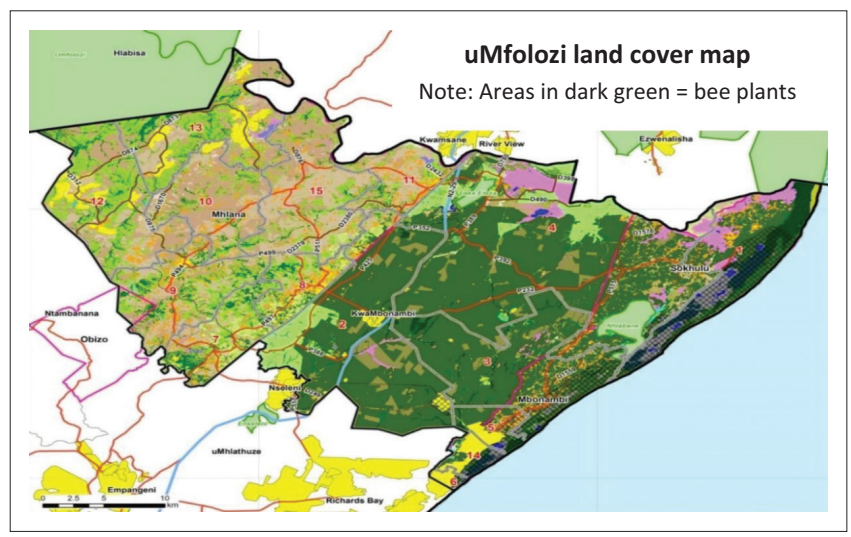

Source: Office of the Municipal Manager: IDP/Development Planning Unit, 2018, Umfolozi integrated development plan, IDP, Umfolozi Municipality

FIGURE 8: uMfolozi land use pattern.

than the $86 \%$ stated by Stats SA (2018) for South Africa. From informal discussions while conducting Bible studies using the African Honey Bee Catechism (Reformed Church Tshwane 2016) in uMfolozi, the researcher has come to realise that there is a lot of gospel message crossover. For example, many of the charismatic churches are also evangelical and most rural African Christians still believe in or practice ancestral worship, because it is so imbedded in their culture. The one reality in the uMfolozi area (if charismatic churches are predominantly regarded as evangelical) is that only 33\% of the worldview in uMfolozi is evangelical. A basic understanding of evangelicalism was included in the AHB Database questionnaire listed in Appendix 1. The results will be discussed later on in this article.

Although poverty is considered from a biblical perspective, affecting holistic wellbeing, a major deliberation needs to be income. It is for this reason that a holistic approach that considers worldview, social, environmental and economic poverty needs to be considered when addressing poverty. As can be seen from Figure 10, the monthly income in the area is extremely low. It is enormously difficult to determine the actual income, because legislation dictates that if South Africans earn an income, they are not allowed to claim state subsidies, so many tend to lie about the reality.

\section{Data analysis}

In order to collect data for managing, reviewing and reporting on the project, the researcher developed a data collecting Android app called 'The Impact app'. The programming map can be viewed in Appendix 1. There are 250 indicator questions that are regularly asked to member families and the results are displayed as information. An example of where this data is used, is in reporting as illustrated in Figure 11. This report was used to provide feedback to stakeholders.

The app also makes use of the Poverty Stoplight ${ }^{6}$ survey, an adaption of the Jobs Fund Productivity survey and an AHB developed Christian survey.

6.Poverty Stoplight is an approach that helps people progress out of poverty by empowering them to understand and map their own choices. It encourages households to participate and own their journeys out of poverty, and provides a clear line of sight of to participate and own their journeys out of poverty, and provides a clear line of sight of
how to get there; at the same time allowing organisations delivering support to measure progress against their programme objectives (Poverty Stoplight SA 2018). 


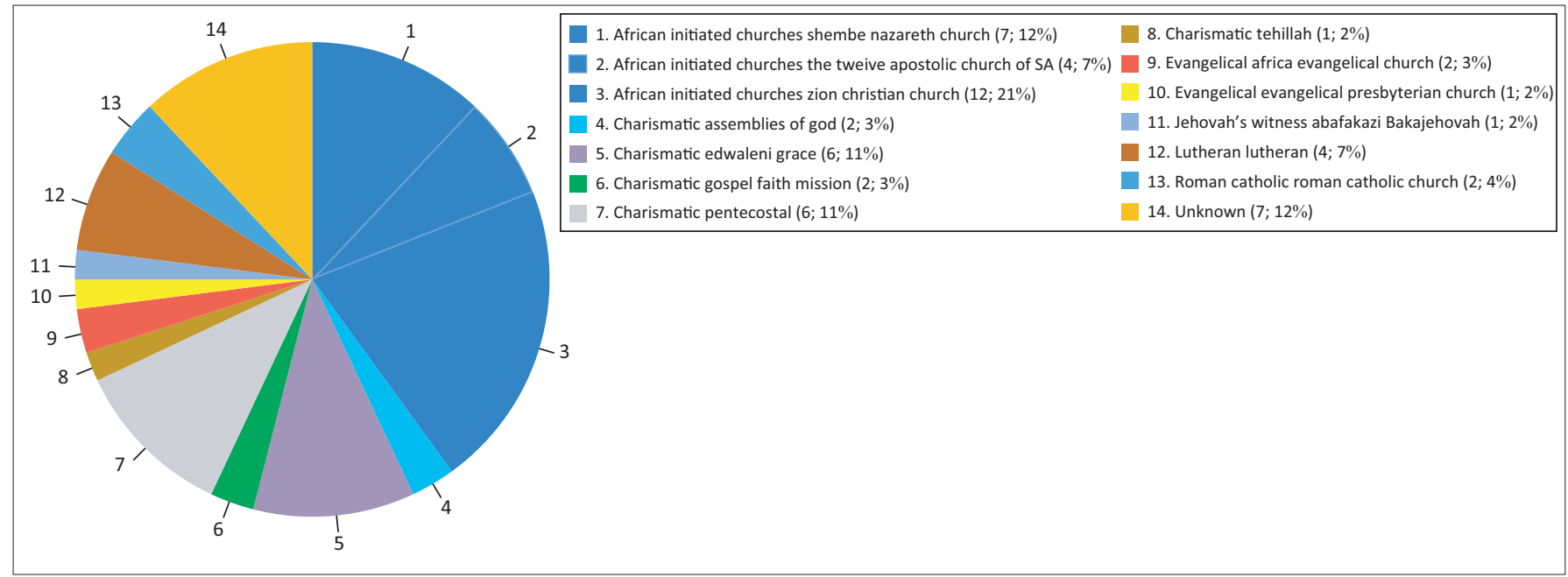

Source: AHB Database, 2018b, 'Christian survey', ed. by African Honey Bee

FIGURE 9: A survey of 58 respondents in the African Honey Bee project on their worldview

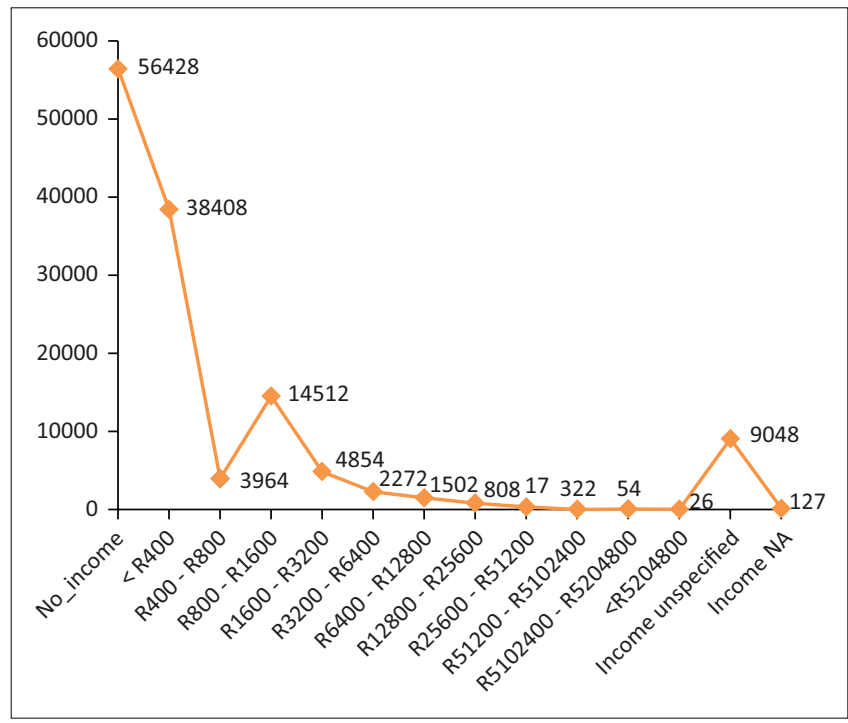

Source: Stats SA, 2017, General household survey, p.82, viewed 07 May 2019, from http:// www.statssa.gov.za

FIGURE 10: Distribution of population by monthly income.

Poverty Stoplight asks 50 poverty related questions (listed in Appendix 2). Interviewees choose one of three answers that best describes their situation. The answers were developed by South African people living in a poverty level similar to the respondents. An example of how each question is asked, can be seen in Figure 12 where three answers are offered: red indicates extreme poverty; yellow indicates an interim stage of poverty; and green indicates that the person considers themselves to no longer be in poverty. AHB has been using Poverty Stoplight for the last four years (three years in uMfolozi) as a management and reporting tool.

As illustrated in Figure 13, data gathered from respondents is shared with them, and used for management purposes and is shared nationally among poverty alleviation organisations.

The app also measures productivity of interactions. The questions asked for the productivity survey are listed in Appendix 3. As the questions have 'yes' or 'no' answers and the survey is undertaken annually, activities can be measured to see the impact of training and mentorship.

The Christian survey questions are listed in Appendix 4. This questionnaire is used to gauge understanding of gospel knowledge among members. This questionnaire is also taken annually to determine changes in knowledge and is used to determine training requirements.

\section{Field reports}

Once a participant had completed making their own beekeeping equipment (demonstrating commitment), they get signed up as a member of the project. The target in 2016 was for 125 beekeepers. Figure 14 illustrates the accumulated number of sign-ups verses the flatline target of 125 .

This self-selection process proved radically successful as can be seen in Figure 14 where the retention rate in 2016 was 85\% higher than the target. In 2017 the number of participants almost doubled due to school awareness programmes where children encouraged their parents to join the project and neighbours joined after seeing how their neighbours' lives were changing.

The results depicted in Figure 15 show a high success rate of hive flatpacks (materials for building a hive) converted into hives. This shows a $99 \%$ success rate of beekeepers converting materials into hives and thereby taking ownership and responsibility of their hives. This is a much higher rate that was experienced by the researcher from previous projects where constructed hives were given to participants (Stubbs 2011:6-11) and retention was less than $10 \%$. The number of hives with bees shows the catch rate as being $40 \%$ of constructed hives, which is normal for the time period (Johannsmeier 2001:17, 24, 50).

Out of the 112 participants who produced honey, 46 also hunted honey showing that $56 \%$ produced honey from hives. A total of 15 tons of honey was produced in 2018 


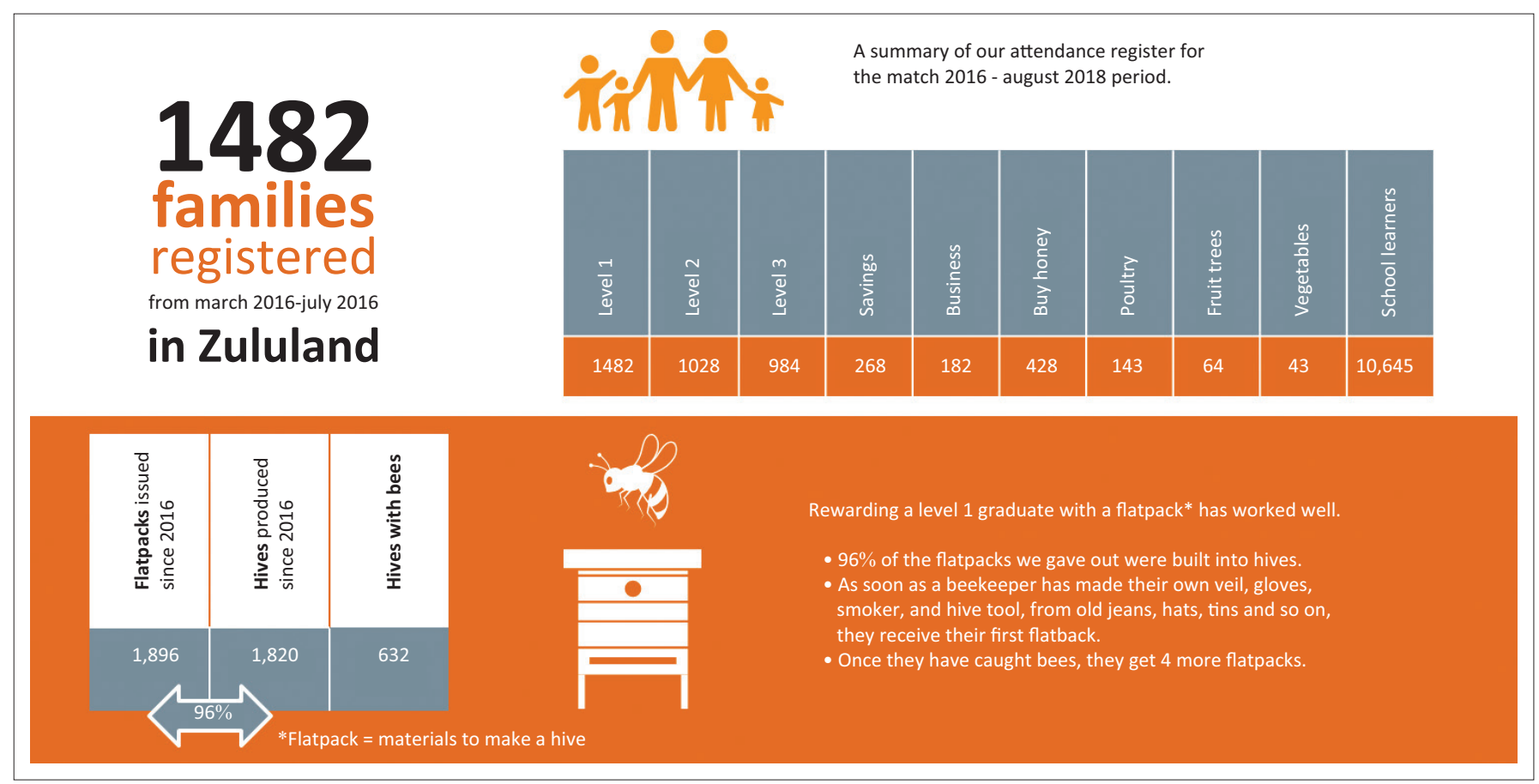

FIGURE 11: An example of a report to stakeholders.

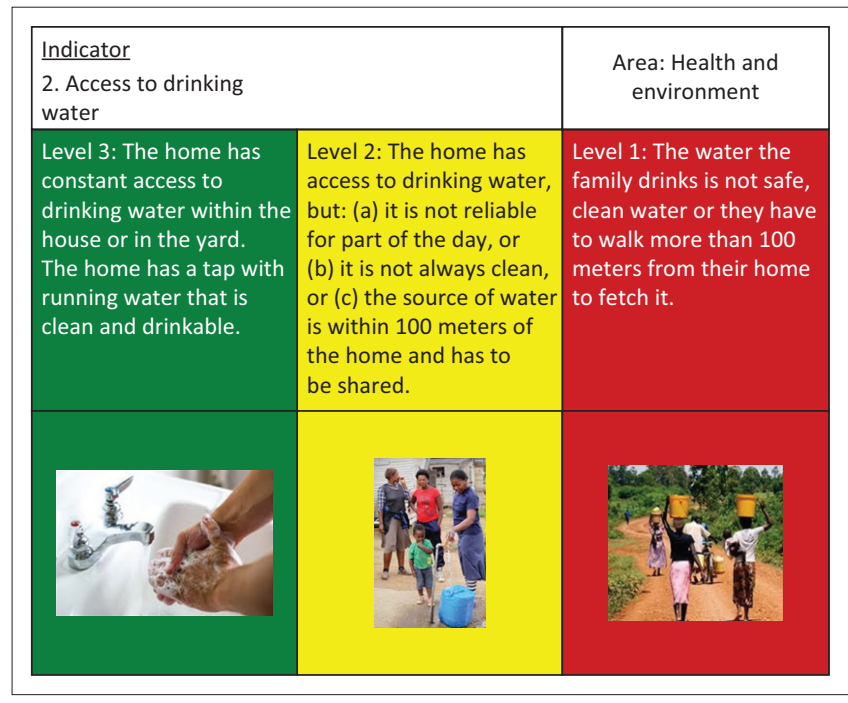

Source: Poverty Stoplight SA, 2018, A movement towards poverty eradication in South Africa, viewed 07 May 2019, from http://www.povertystoplight.org.za

FIGURE 12: An example of a Poverty Stoplight question in isizulu.

(AHB Database 2018d), which means that 8.4 tons were produced from hives. The aim for number of hives per beekeeper is 5 , but the figures in Figure 15 shows that the average number of hives per respondent is 1.6. It can be assumed therefore, according to these figures, that if the number of hives per respondent can be increased to 5 , there could be an increase of 17.9 tons of honey for the same number of respondents. Furthermore, only $15 \%$ of the respondents produced honey from their hives. If we assume a conservative figure of 1.6 hives per respondent, this assumes that 178 hives produced 8.4 tons, or hives have bees and therefore produced an average of $47 \mathrm{~kg}$ each. This assumption is unrealistic as an average South African yield. Thus, we should rather assume those respondents who produced honey from their hives and

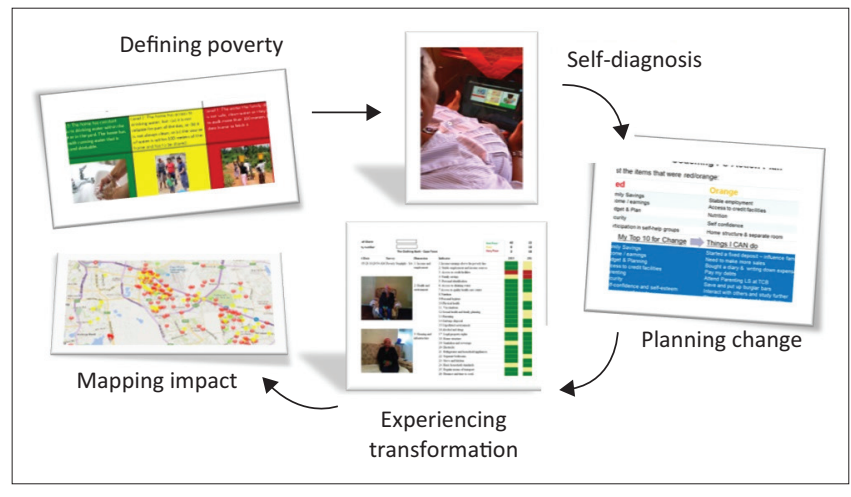

Source: Poverty Stoplight SA, 2018, A movement towards poverty eradication in South Africa viewed 07 May 2019, from http://www.povertystoplight.org.za

FIGURE 13: A diagramme illustrating how the Poverty Stoplight functions.

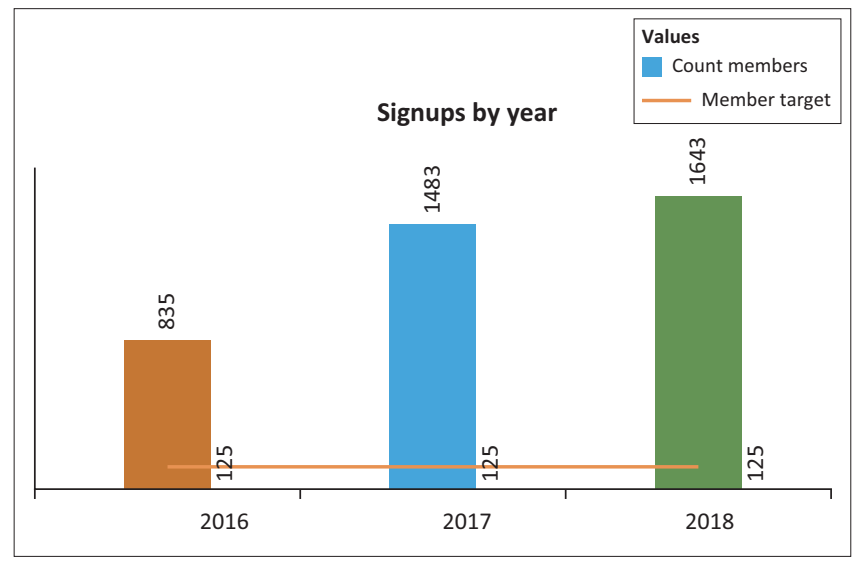

Source: AHB Database, 2018c, 'General', ed. by African Honey Bee

FIGURE 14: Accumulated sign-ups per year with the target illustrated as a line.

own five hives each, bring the average of honey, produced per hive, to $15 \mathrm{~kg}$ per hive, which is a good South African average yield (Johannsmeier 2001:160-162). 


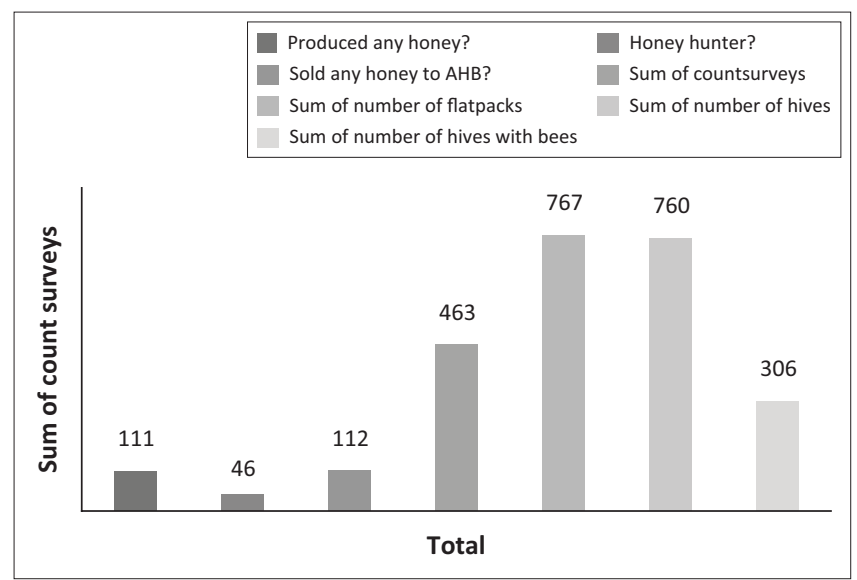

Source: AHB Database, 2018f, 'Telephone survey December 2018', ed. by African Honey Bee FIGURE 15: Flatpacks, hives, hives with bees, surveys, honey produced and honey hunters.

It is interesting to look at an overall Poverty Stoplight survey of the whole project from 2015 until 2018 to see the changes in perceptions in poverty. Figure 16 shows 'very poor' coming down for 3 years and then going up slightly. 'Not poor' also goes down slightly and then in 2018 goes up significantly. 'Poor' shows a steady increase and then decrease in 2018 when it is replaced by 'not poor'.

The increase in 'very poor', seen in 2018, is better understood when viewing Figure 17. Here it can be seen that there is an increase in 'very poor' answers for security, distance from work, sanitation and sewerage, garbage disposal, health care and drinking water - perhaps depicting an increased environmental and self-awareness.

In Figure 18 the key indicators that AHB directly affects the people in the project are illustrated: one can see a distinct move from 'very poor' to 'poor' and 'not poor'. The savings groups were introduced in 2017 and one can already see the impact in 'access to credit facilities' and 'family savings' in 2018.

Figure 19 depicts the positive change as influenced by AHB over the four years. The increase of 'not poor' for the selfworth indicators in 2018, is attributed to the starting of savings groups in 2017. Overall poverty is seen to reduce, indicating that the training and mentorship activities, actioned by $\mathrm{AHB}$, are having the desired reaction.

Another interesting graph is the productivity graph that measures the increase or decrease of activities during a year. As can be seen, there is a general increase in activities (especially with beekeeping activities) that shows effectiveness in training and mentorship. Areas with a low increase will be focused on.

When beekeeping proficiency was measured, an overall improvement was also seen as illustrated in Table 2. The only indicator that decreased, was keeping apiaries small enough. This aspect of the project caused a failure of production in other areas due to overstocking and is therefore an area of concern.

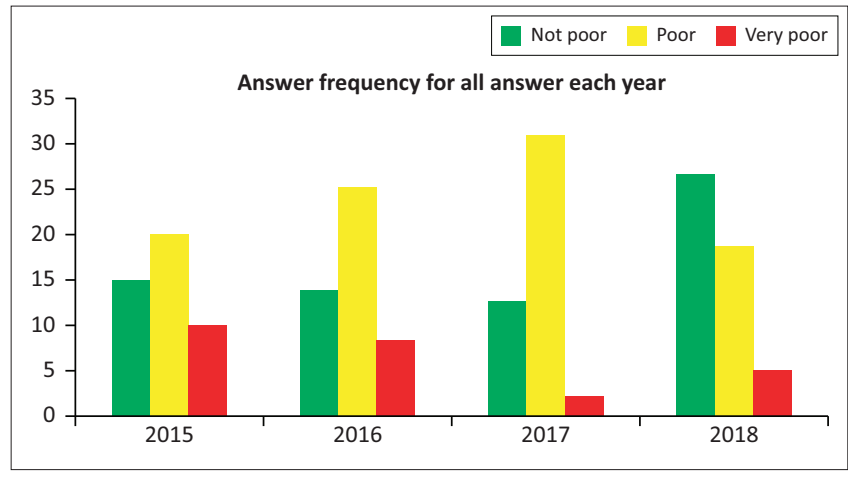

Source: AHB Database, 2018e, 'Poverty stoplight survey', ed. by African Honey Bee FIGURE 16: Poverty Stoplight over 4 years.

Honey hunter fire reduction has been witnessed in the project area as a result of awareness and training. In a thesis on the project, Kiara Ricketts (2018) found that the total number of forest fires and those attributed specifically to wild honey hunters showed a decreasing trend from the years 2014-2017 (Figure 21).

While the total number of fires had gradually decreased, the number of honey hunter fires also more than halved in the year 2017, a year after the introduction of the AHB programme. Ricketts (2018:13-14) quoted Zululand Fire Protection Officer, Tony Roberts: 'The honey hunters cause a lot of fires in the timber plantations by smoking the ground and log hives, and ultimately causing uncontrolled fires.' The importance of frequent training of the adult honey hunters, is that they are mostly migrant labourers, so every year there are a whole lot of new honey hunters that move into the area. As a result, AHB has had to do ongoing training on a yearly basis to train up all the new people.

Ricketts (2018) conducted interviews with honey hunters and concluded that they were often aware of the negative impacts of honey hunting on the environment. For example one response was:

'We go into the plantations, find the beehives and smoke the bees using a fire. Sometimes when the bees sting too much, we run away and leave the fire.' (Interviewee 13, 24 year old male honey hunter; p. 14)

However, for many it is their sole source of livelihood and they are just trying to make ends meet. For example:

'My family gets all of the money from hunting and selling honey, we don't have any other employment.' (Interviewee 14, 24 year old male honey hunter; Ricketts 2018:14).

Honey hunters expressed interest in converting to beekeeping with hives, for example Interviewee 14, a 24 year old male honey hunter said, as reported by Rickets (2018):

I would definitely like to become a beekeeper. I could have the hives right in my backyard. Then I would not have to walk far distances to rob the wild hives and try sell honey on the side of the road. (p. 14) 


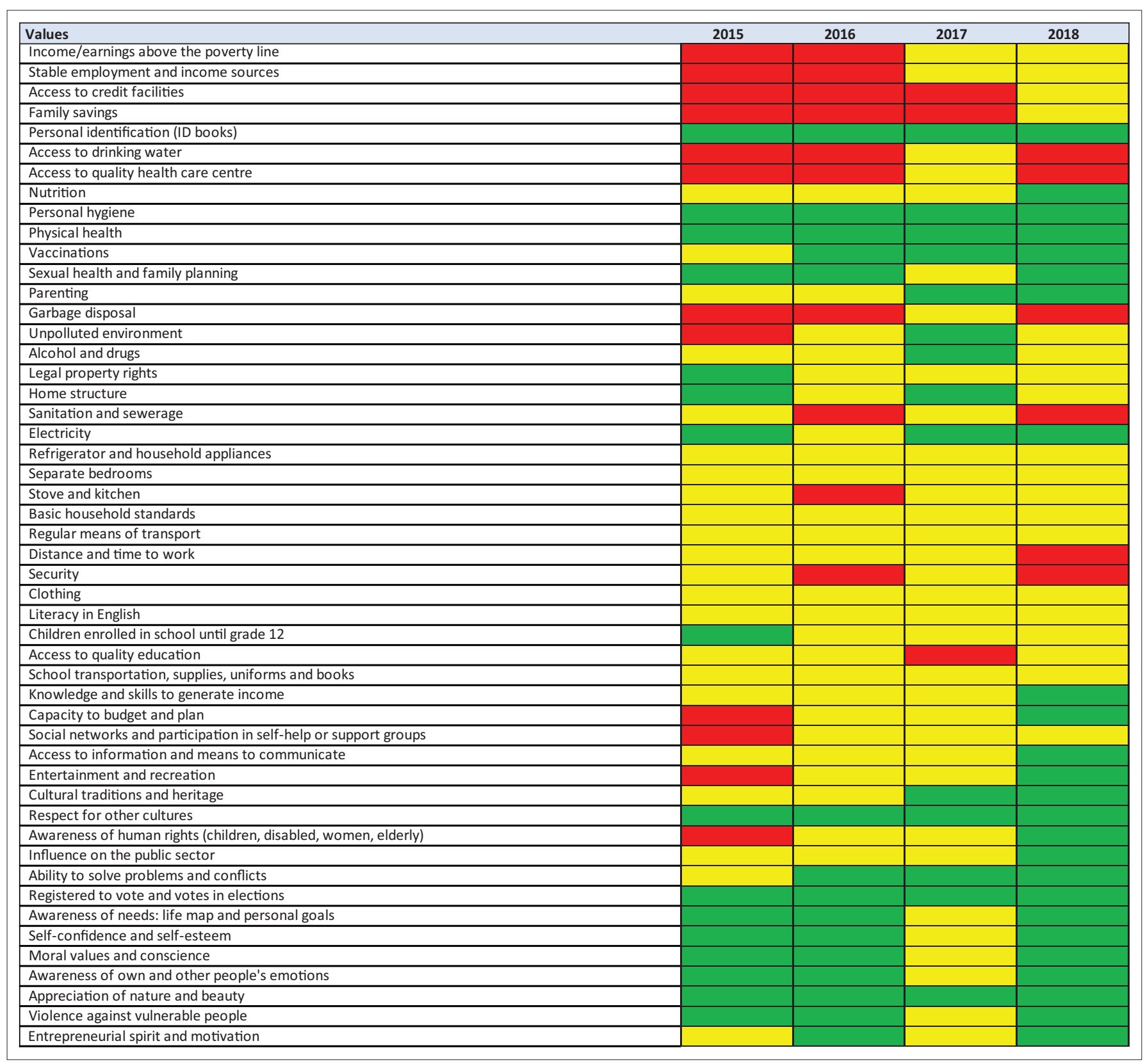

Source: AHB Database, 2018e, 'Poverty stoplight survey', ed. by African Honey Bee FIGURE 17: Poverty Stoplight detail of Figure 16.

Ricketts (2018) quotes Tony Roberts who spoke of the potential benefits this could have for forest conservation in the area:

Transitioning from honey hunting to beekeeping could definitely impact on fire frequency in the future. It could be a solution that would potentially reduce the number of honey hunters, but there will always be wild hives in the timber plantations. (p. 14)

When measuring the effectiveness of evangelism and discipleship, one can clearly see an increase in knowledge and activity in Figure 22. With some doctrinal concepts such as understanding sin, there was a radical improvement. With others such as those owning a Bible, there was less of an increase. The questions and answers are as follows:

- What is sin?

- Do not know

- Doing something wrong in God's eyes
- Can your sins be forgiven?

- Yes

- No

How are you sins forgiven?

If I change and become a good person or if I pay something Jesus died on the cross as payment for my sins

- How frequently do you attend church activities (services)?

- Attending at least once a month

- Attending more than once a month

- Not attending

- How often do you pray?

- Never

- Sometimes

- Constantly

- Do you own a Bible?

- Yes

- No 


\begin{tabular}{|l|l|l|l|l|}
\hline Values & 2015 & 2016 & 2017 \\
\hline Income/earnings above the poverty line & & & & \\
\hline Stable employment and income sources & & & & \\
\hline Access to credit facilities & & & & \\
\hline Family savings & & & & \\
\hline Nutrition & & & & \\
\hline Knowledge and skills to generate income & & & & \\
\hline Capacity to budget and plan & & & & \\
\hline Self-confidence and self-esteem & & & & \\
\hline Moral values and conscience & & & & \\
\hline $\begin{array}{l}\text { Awareness of own and other people's } \\
\text { emations }\end{array}$ & & & & \\
\hline Appreciation of nature and beauty & & & & \\
\hline Entrepreneurial spirit and motivation & & & & \\
\hline $\begin{array}{l}\text { Sum of Awareness of needs: life map and } \\
\text { personal goals }\end{array}$ & & & & \\
\hline
\end{tabular}

Source: AHB Database, 2018e, 'Poverty stoplight survey', ed. by African Honey Bee FIGURE 18: Poverty Stoplight of African Honey Bee activities.

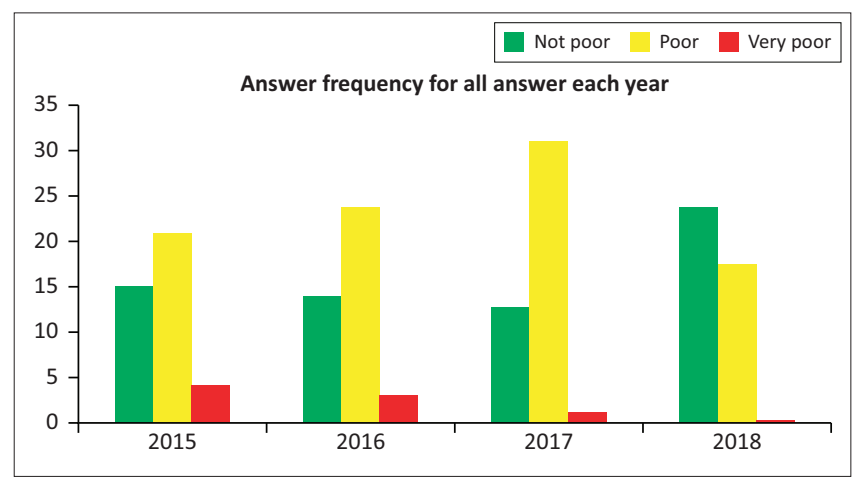

Source: AHB Database, 2019b, 'Productivity survey', ed. by African Honey Bee FIGURE 19: Poverty Stoplight of African Honey Bee activities.

TABLE 2: Proficiency questions from the productivity survey.

\begin{tabular}{lcc}
\hline Beekeeping proficiency (140 families) & $\mathbf{2 0 1 7}$ & $\mathbf{2 0 1 8}$ \\
\hline Do you have hives with frames & $89 \%$ & $100 \%$ \\
\hline Do you use protective clothing when bee keeping & $90 \%$ & $91 \%$ \\
\hline Do you use a smoker when beekeeping & $90 \%$ & $91 \%$ \\
\hline Do you leave honey for the bees after harvesting & $90 \%$ & $82 \%$ \\
\hline Do you use a sterilised food grade bucket when harvesting & $90 \%$ & $91 \%$ \\
\hline Do you manage your brood & $90 \%$ & $82 \%$ \\
\hline Do you keep apairies small enough to produce honey & $90 \%$ & $82 \%$ \\
\hline Do you keep apairies in areas where there is food for the bees & $90 \%$ & $91 \%$ \\
\hline Do you protect your hives from vandals/thieves & $90 \%$ & $100 \%$ \\
\hline Do you protect your hives from fire & $90 \%$ & $100 \%$ \\
\hline Do you protect your hives from ants & $90 \%$ & $100 \%$ \\
\hline Do you protect your hives from honeybadgers & $89 \%$ & $100 \%$ \\
\hline
\end{tabular}

Source: AHB Database, 2019b, 'Productivity survey', ed. by African Honey Bee

- How often do you read the Bible?

- Never

- A few times a month

- Everyday

- What do you think of when you hear the name Jesus Christ?

- Famous man

- Agod

- God
To measure social cohesion and relearning ubuntu, the researcher considered the savings activities in Table 3. From identifying problems of self-worth (identified in Figure 18 and 19) the introduction of savings groups in 2017 had a very positive impact on the project. As can be seen from the table, 16 groups were established, two stopped and the rest have been successful. The two groups that stopped, indicated that they will resume in 2019.

As can be seen in Figure 23, Table 2 and Figure 20, enterprise activity has steadily increased over the project period. The reason for the increase is assumed to be the method of practical enterprise training, enabling access to credit via savings groups, access to markets, logistical and technical support and mentorship.

Micro-franchising as a systems structure, has been successful as can be seen from Figure 20, Figure 23, Figure 24 and Table 3. Similarly, to a primary and secondary coop structure, micro-franchising enables producers to belong to a support platform that provides training, logistical and technical support, access to market and a share in the value chain. The difference between coops and micro-franchising is that the producers are not forced to be members of the project. Their contribution and benefit are based on supply.

Besides illustrating the annual honey flow, Figure 24 shows a reduced weight of honey bought, compared to that harvested. The main reason for this was the loss in weight from waste after the honey was processed.

\section{Ethical consideration}

This article followed all ethical standards for carrying out research without direct contact with human or animal subjects.

\section{Discussion}

Some practical lessons have been learnt from the AHB project in the uMfolozi area of South Africa that may enrich the theology and practice of integral mission:

\section{Integral mission}

The purpose of the project through the five marks of mission was considered and proposed by Wright (2015:6-36), namely:

1. proclaiming the good news of the kingdom;

2. teaching, baptising and nurturing new believers;

3. responding to human need by a loving service;

4. seeking to transform the unjust society; and

5. creation care.

Then the researcher realised that the work being done by AHB is a valid missional project. There is proclamation of the gospel through word and deed activities, there are teaching, incorporating and discipling activities, there is a motivation to serve out of love (with a knowledge of God's love), there is action being taken to transform an unjust society, and the project stimulates creation care. 


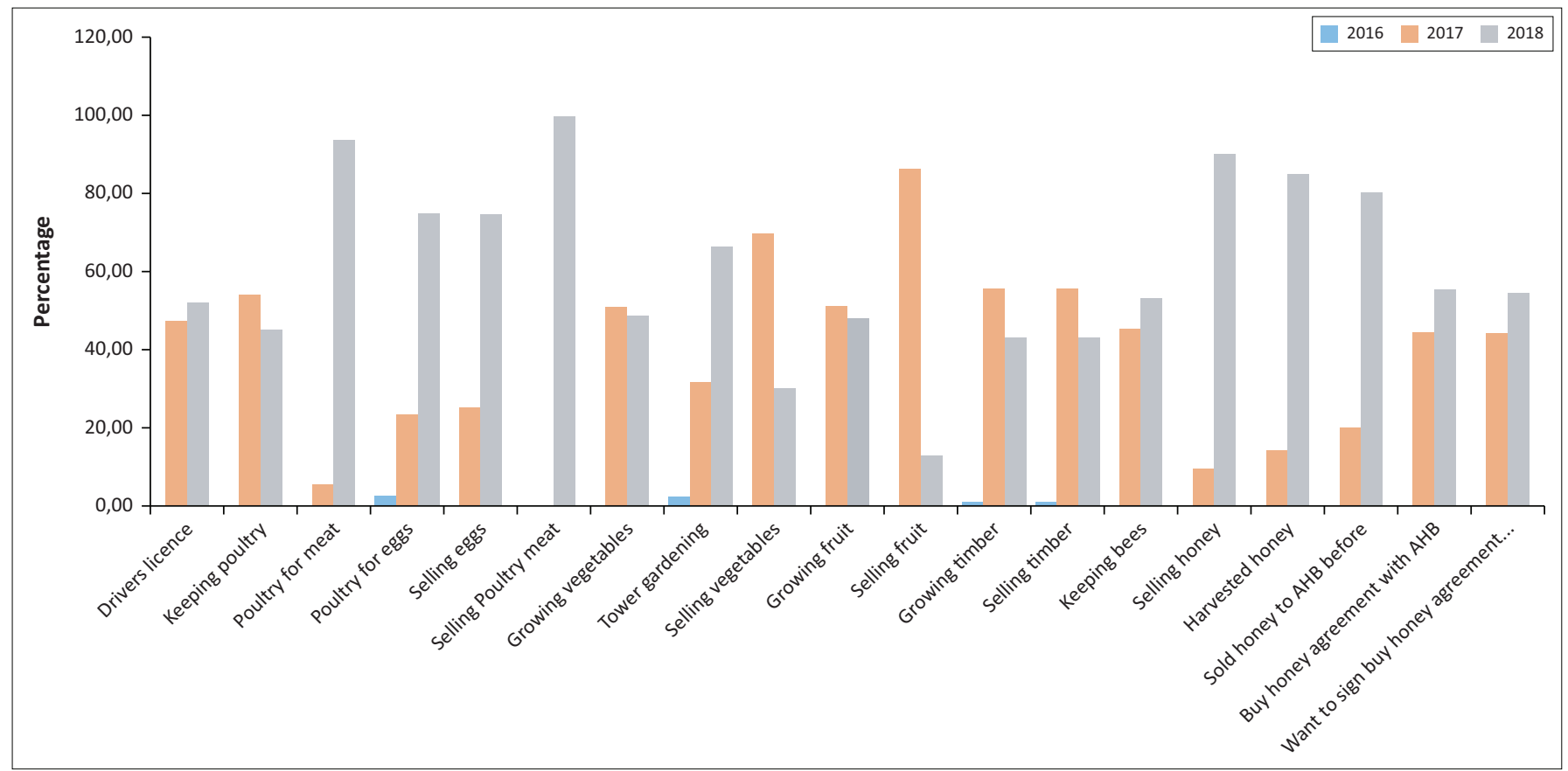

Source: AHB Database, 2019b, 'Productivity survey', ed. by African Honey Bee

FIGURE 20: Annual increase or decrease of activities.

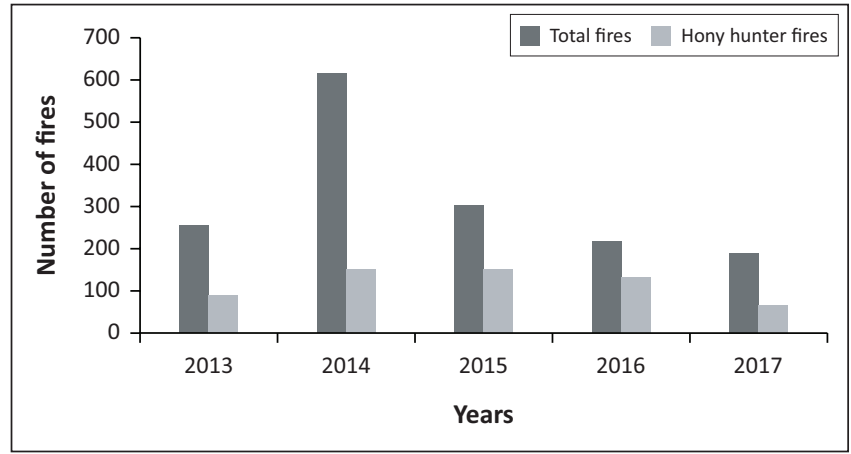

Source: Ricketts, K., 2018, Improving livelihoods and forest conservation through beekeeping in northern KwaZulu-Natal, p. 14, Rhodes University, Grahamstown

FIGURE 21: Prevalence of wild fires in Zululand and those attributed to wild honey hunters.

The gospel is proclaimed through the teaching and witnessing of the gospel. Participants are provided with Bibles in the language of their choice. They are taught to read their Bibles through regular Bible study. $\mathrm{AHB}$, being an organisation operating according to biblical principles, provides a deedbased witness that contributes towards the proclamation. Participants are invigorated to seek the truth because they witness transformation of their own lives through their participation and involvement in the project.

Although most participants call themselves Christians, most have a distorted view of the gospel. The project therefore does not promote a specific denomination, rather it presents the Word of God in a way that creates channels for the working of the Holy Spirit. An example of this is where Nazareth Baptist Church ${ }^{7}$ priests are edified (and corrected in their theological view) by reading and studying the Bible.

7.The Nazareth Baptist Church (alternatively called 'The Nazarite Church' or 'iBandla lamaNazaretha') is the largest African initiated church founded by Isaiah Shembe in 1910 (Fisher 2010).
Love, when understood from a biblical perspective, is the greatest contributor to success in the project. An integral Christian understanding of ubuntu by the predominantly Zulu participants, strengthens a contextual understanding of the love of Jesus, and how it is replicated in mutual love and compassion in the community.

In the case of uMfolozi, we see all the effects of sin: (1) dependency on grants, which results in fear, laziness and apathy; (2) economic 'side-lining' by multi-nationals and the government who used Colonialism ${ }^{8}$, Apartheid ${ }^{9}$ (and now Marxism ${ }^{10}$ ) to exclude the impoverished communities of uMfolozi from the mainstream economy; and (3) the spread of syncretism by church leaders unversed in the gospel, which has led to false teachings such as the prosperity gospel, which offers a false hope that results in despondency. The gifts of faith and hope in Jesus, enable participants to develop a faith and hope in themselves that stimulates an attitude of dignity. The socio-economic and political environment has led to a dependency on unjust corporate and governmental systems that participants realise they can break free from.

The project teaches climate mitigation methods of agriculture, which are in their nature models of good biblical stewardship.

8. Colonialism is the policy of a foreign politics, seeking to extend or retain its authority over other people or territories, generally with the aim of opening trade opportunities. The colonising country seeks to benefit from the colonised country or land mass. Many of the colonised countries were not countries at all prior to colonisation. In the process, colonisers imposed their religion, economics and medicinal practices on the natives (Lorenzo 2010:5).

9.Apartheid was a system of institutionalised racial segregation that existed in South Africa from 1948 until the early 1990s. Apartheid was characterised by an Africa from political culture based on baasskap (or white supremad by an authoritarian political culture based on baasskap (or white supremacy), which encouraged state repression of black African, mixed race and Asian South Africans
for the benefit of the nation's minority white population (Mayne 1999:52).

10.Marxism is a method of socioeconomic analysis that views class relations and social conflict, using a materialist interpretation of historical development and takes a dialectical view of social transformation (Wolff \& Resnick 1987:130). 


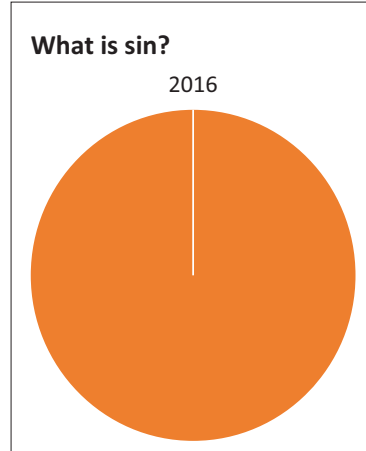

Can your sins be forgiven? 2016

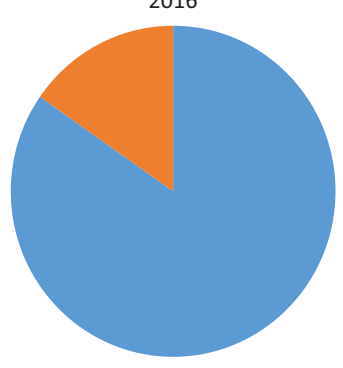

How are your sins forgiven? 2016

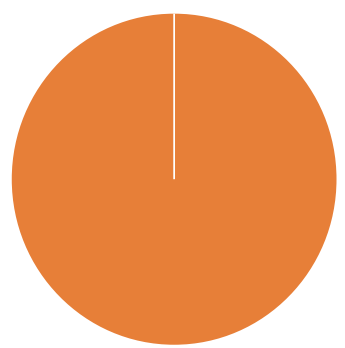

How Frequently do you attend chruch?

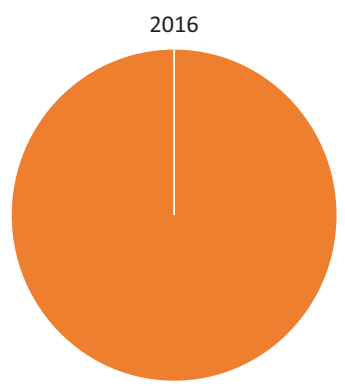

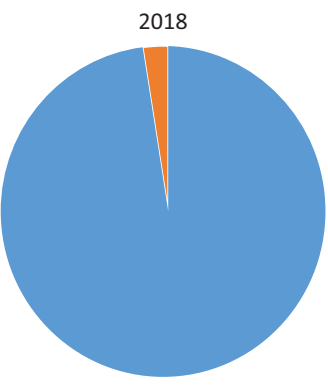

2018

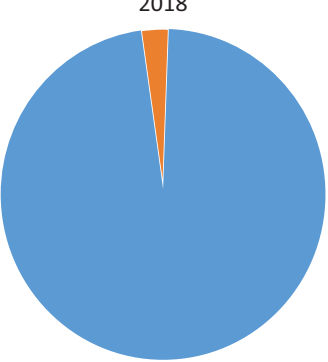

2018

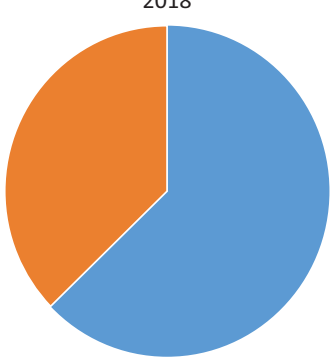

2017

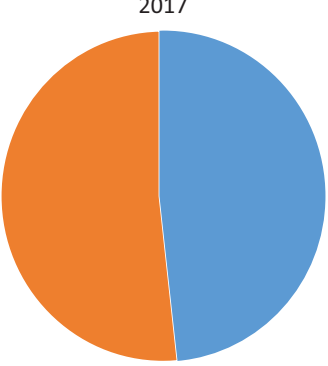

How frequently do you pray?

2016

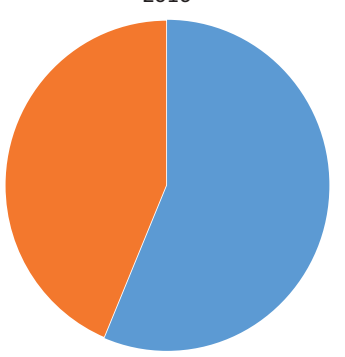

Do you own a bible?

2016
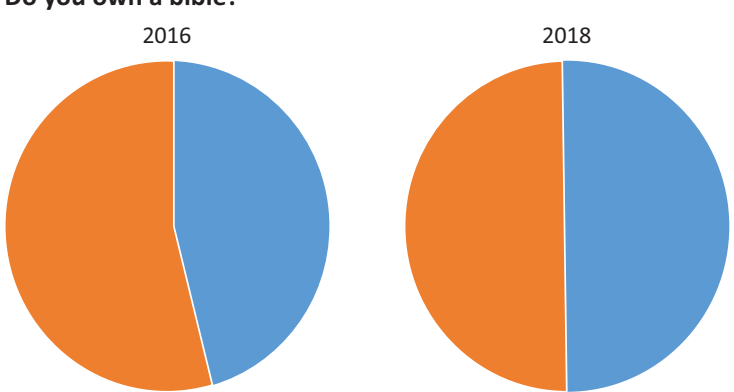

How often do you read the bible?
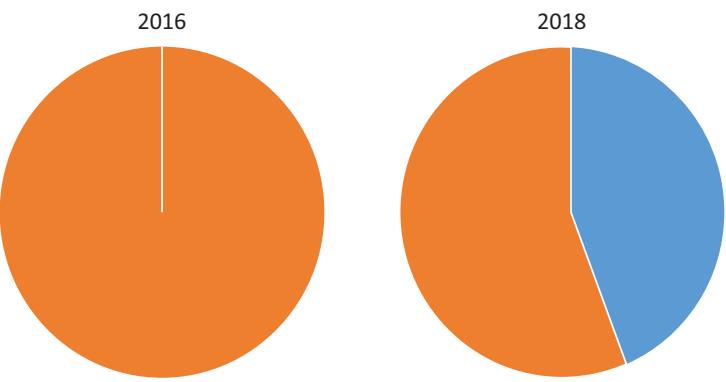

What do you think of when you hear the name of jesus christ?
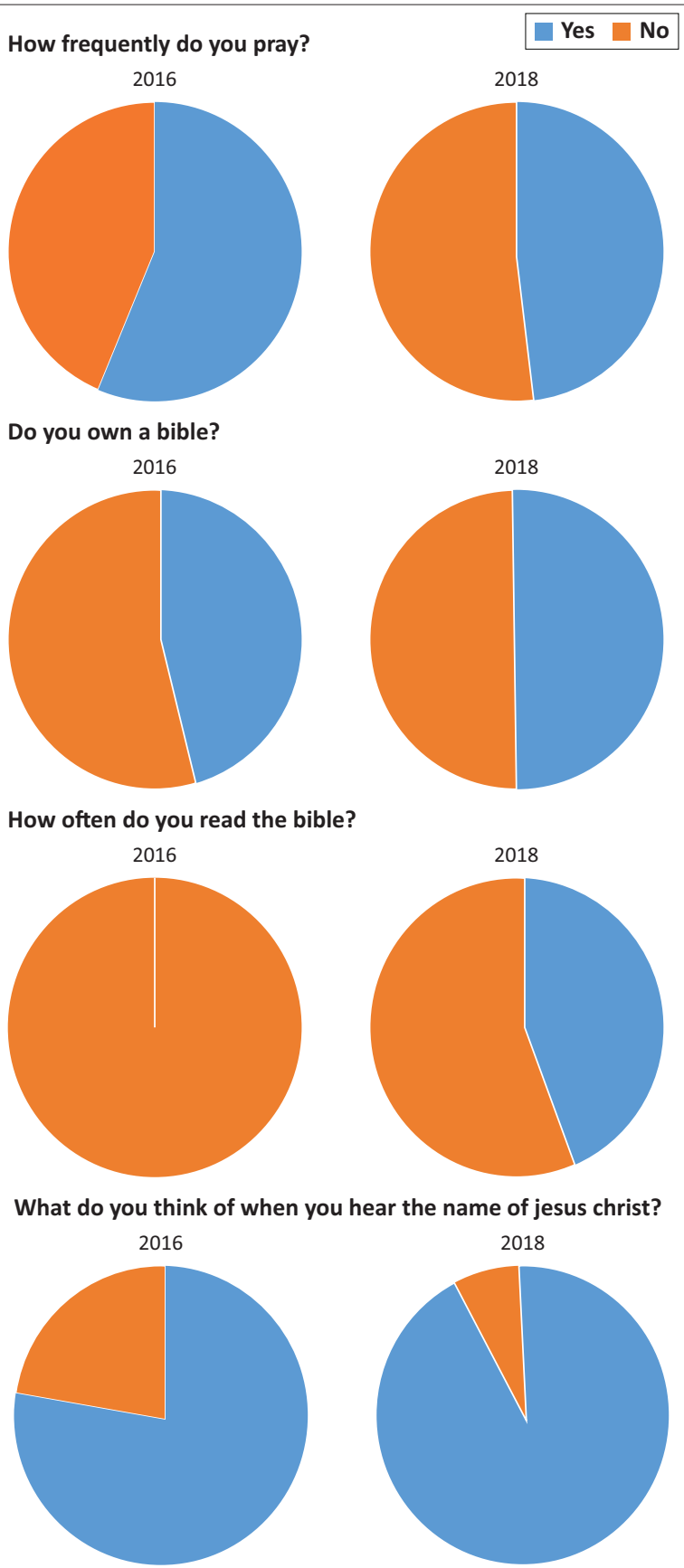

Source: AHB Database, 2018b, 'Christian survey', ed. by African Honey Bee

FIGURE 22: Christian survey of 213 people interviewed in 2016 and again in 2018

When practises are undertaken God's way, the environment is managed in a way that is sustainable and nurturing in nature.

\section{Self-selection: Asset-Based Community Development}

In previous projects where selection processes were motivated by politics, retention of participants was very low. The AHB project only signed up participants once they demonstrated a certain level of commitment. Showing participants how to use resources available to them to make equipment and tools to start income, generating activities proved highly transformational. Participants not only experienced an 'I can' experience, but they were also motivated to do more and share their experience with their families.

\section{Awareness of self-worth - Knowledge of word and deed}

The participants grew in their understanding that they are created in the image of God and have talents and gifts of the Holy Spirit to serve God, each other and their community. They gradually developed faith and trust in Christ alone, and were liberated from enslavement to an attitude of dependency on governmental provision or donor funding for all their needs. The biggest obstacle during the implementation was 
TABLE 3: Savings data: Savings groups from September 2017 to September 2018.

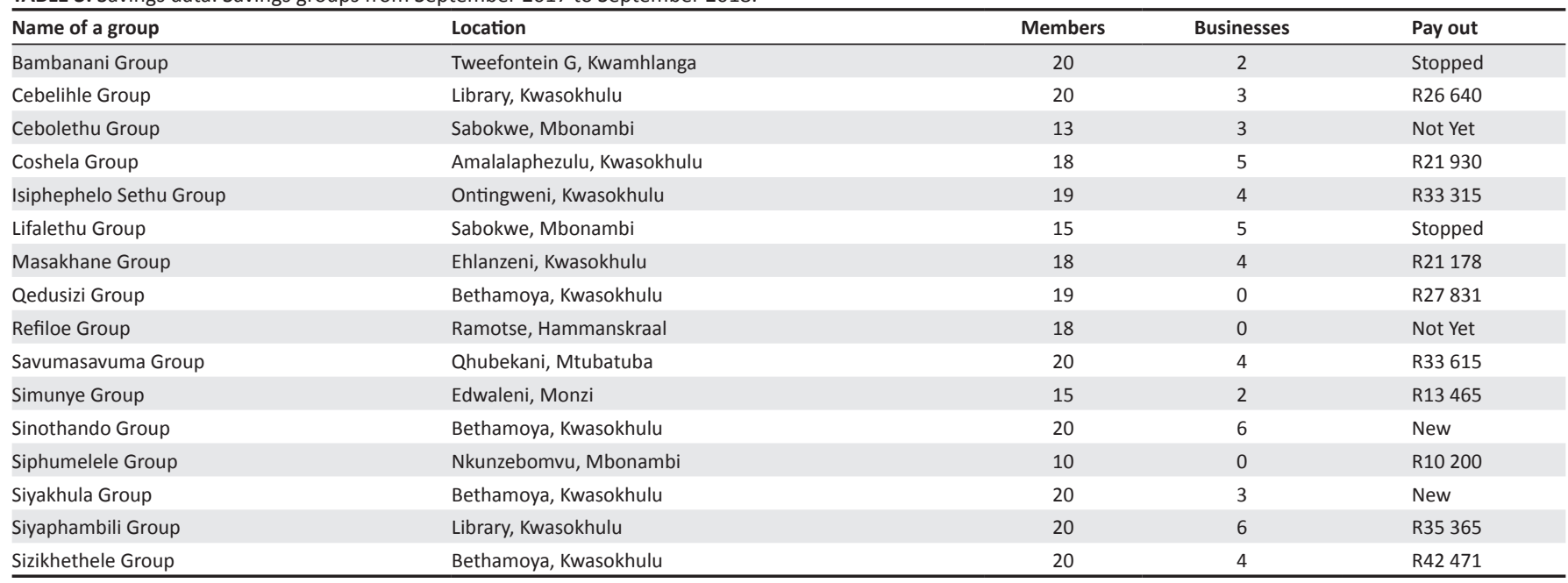

Source: AHB Database, 2019c, 'Savings data', ed. by African Honey Bee

\begin{tabular}{|l|l|l|l|l|}
\hline Values & 2015 & 2016 & 2017 & 2018 \\
\hline Income/earnings above the poverty line & & & & \\
\hline Stable employment and income sources & & & & \\
\hline Access to credit facilities & & & & \\
\hline Family savings & & & & \\
\hline Knowledge and skills to generate income & & & & \\
\hline Capacity to budget and plan & & & & \\
\hline Entrepreneurial spirit and motivation & & & & \\
\hline
\end{tabular}

Source: AHB Database, 2018e, 'Poverty stoplight survey', ed. by African Honey Bee FIGURE 23: Poverty Stoplight micro-enterprise indicators.

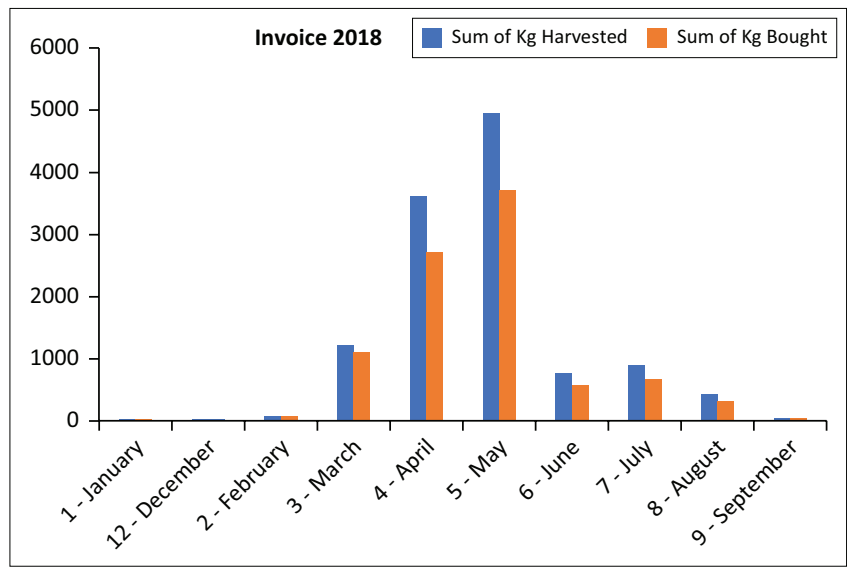

Source: AHB Database, 2019a, 'Honey value chain', ed. by African Honey Bee FIGURE 24: Honey value chain.

to transform a mindset of relief that creates a culture of dependency and eventually humiliate people. Due to political leaders using social grants as a type of reward or exchange system for votes, the vast majority of the community thought of themselves as fundamentally deficient and victims who are incapable of taking charge of their own lives.

\section{Microfinance}

The introduction of savings groups had many positive effects on the project such as instilling a sense of corporate responsibility, social cohesion and ubuntu. The fact that members invested their own money (often from social grants), incentivised a culture of commitment. Self and corporate discipline developed, as groups developed their own governance procedures. Rules and fines for arriving late or missing a savings meeting not only increased the savings but also developed discipline.

Each monthly meeting is started with a devotional based on the African Honey Bee Catechism and Bible reading. These Bible studies helped to put the gospel in perspective with day to day living. Most members reported that they would repeat the study with their families each night. Aspects of understanding economy often led to a better understanding of biblical concepts and vice versa.

Linked to savings, training was a practical hands-on approach to managing money and using it to start and grow microbusinesses. Principles of business were identified by practical application, extracted and used to develop business plans for the income, generating ideas developed by the individuals as well as the businesses-in-a-box ideas, presented by AHB.

Other advantages of the group structure included the purchasing of low-cost inputs for the businesses-in-a-box, because they could be bought in bulk and the combined access to market. The greatest benefit, however, was the access to credit that the groups provided. Members could borrow from the group to start micro-businesses, and this resulted in a flurry of economic activity in communities of previously dormant members, locked into a state of dependency.

\section{Effectiveness of training}

Key to successful training has been the enabling effect of self-selection and the ABCD methodology. Members are incentivised to try, because their rewards are immediate, 
tangible and practical. Using materials available to them such as scrap, natural resources or recycled waste, members realised that they did not need to sit waiting for handouts, they could change their lives with what they had. Assets in ABCD are identified as gifts and talents, or abilities that the individual or family might possess or develop as well as the resources available to them (Mathews 2013). Training therefore has been more of an enabling process where participants are practically able to make the equipment they need and use it effectively to change their lives.

\section{Micro-enterprise}

The methods of micro-enterprise training have succeeded in both enabling members to start income generating activities as well as manage the businesses-in-a-box according to basic business principles that enable profit generation. It has been critical to develop micro-enterprises as opposed to enterprises of scale. Micro-enterprises do not need capital expenditure due to the ABCD approach. Members collect and build their own equipment, then borrow money from their group for their start-up operating costs. An example is where a member builds a chicken enclosure and brooder, and borrows R350 for 12 day-old-chicks, $10 \mathrm{~kg}$ starter feed, $20 \mathrm{~kg}$ grower feed, $10 \mathrm{~kg}$ finisher feed and a packet of vitamins. The chicks are grown for six weeks and sold for around R800. The loan (and interest) is repaid, profiting the member R415.

\section{Micro-franchising}

Micro-franchising has been fundamental in enabling successful training, logistics and technical support, access to market and share in value chain profits. The main benefit of micro-franchising has been micro-enterprise replication. By offering businesses-in-a-box solutions as part of the micro-franchising, members have been enabled to be more productive in production of food. In addition, they often have been enabled to generate additional income from production. The methods are not new expensive methods requiring substantial capital, but rather more productive efficient ways of producing the same produce that is already being produced. For example, Zulu hens are trained to sleep and lay in mobile enclosures, and fed layer feed to produce eggs for personal consumption and for sale. Selling eggs is encouraged, even if it simply covers the costs of the layer feed. A 10-hen business can generate a profit of R225 per month.

The second biggest advantage of franchising, is the access to market. An example is how AHB collects all the honey produced by the members and sells it through Peels Honey (2019). Peels not only pay for the honey on receipt, but they also give 50\% of the profit back. During 2018 the price paid for honey was R50 per kg and the profit share was about R25. This is illustrated in Figure 3. This enabled the family members, the micro-franchisees, to earn R46.25 per kg from the base price, and R7.50 per $\mathrm{kg}$ from the profit share. It enabled the group coordinators, the micro-franchisors, to earn R1.25 per $\mathrm{kg}$ from the base price and R2.50 per $\mathrm{kg}$ from the profit share. In the expansion plan, the facilitators, social franchisees, will earn R1.25 per $\mathrm{kg}$ from the base price and R12.50 per $\mathrm{kg}$ from the profit share, and the social franchisor, $\mathrm{R} 1.25$ per $\mathrm{kg}$ from the base price and R2.50 per $\mathrm{kg}$ from the profit share. This structure of sharing and incentives enables the micro-franchising to be sustainable, fair, incentivised at all levels, and achieve the desired impact of sustainable poverty alleviation.

Social franchising will be used for replication and expansion of the project, by training and equipping young men as facilitators and leaders who will replicate the micro-franchise model in other areas. These young leaders will be trained how to manage 20 to 30 groups of 20 people (family representatives) each. They will also be trained in the Explore Correspondence Course (George Whitefield College 2019).

Because of the group forming nature of franchising (where groups of families who are walking distance from their meeting venue, gather on a regular basis), franchising is not only an excellent structure for economic transformation, but also provides a practical platform for evangelism and discipleship. It is this physical and spiritual character of the transformation that led the authors to believe that this method of mission is integral.

\section{Conclusion}

The sustainability method of this project - micro-franchising for Mission - has been successful on various levels due to the development, testing and implementing of some interlinking approaches. The overall approach has been integral or holistic in two ways: (1) proclamation and demonstration (Samuel 2018) - it has been approached from a biblical perspective of the integration of word and deed where physical witness has played a major role in the acceptance and adoption of proclamation witness; and (2) instead of just focusing on one activity, several connecting and supporting activities make up the benefits of belonging to the project. Beekeeping, as a core activity, enabled self-awareness and thereby positive transformation through the construction of beekeeping equipment from scrap, and self-confidence that comes from working with bees.

Transformation of community came from the groups of transformed individuals learning to work together to save and manage corporate money. These groups firstly became community stokvels or banks, then farmers associations and then micro-churches. They learnt to function in a similar way to Calvin's Geneva Church (Haykin \& Robinson Sr 2014; Labuschagne 2009).

The sequence of events combined with the three biblical attributes of hope, faith and love enabled transformation to occur. The support mechanisms and incentives of franchising enable self-sustainability and continuation of the project. The sequence is experienced by a member in the following way: (1) Hear about training (usually through word of mouth); (2) attend training at a venue that is walking distance from 
your home; (3) realise that there are no handouts, but demonstration of commitment can lead to membership; (4) realise that you can do it with what you have; (5) learn the gospel message of salvation; (6) realise what dependency on Christ (and not on other humans) means; (7) immediately see the work of your hands and start to understand the enabling freedom offered in Christ; (8) seek wisdom because you have experienced hope and liberty; (9) involve your whole family; (10) get involved, share and benefit with and for your community; and (11) share, witness and proclaim out of gratitude and a genuine concern for others.

Faith, hope and love were learnt, contextualised and demonstrated as witness, proclamation in the understanding and application of the gospel message and in integral and missional involvement therein - all to the ultimate goal: to bring all glory to God.

\section{Acknowledgement Competing interest}

The authors have declared that no competing interest exist.

\section{Authors' contributions}

P.J.B. acted as study leader, provided material for in-depth theological reflection; G.S. was the field researcher, gathering and analysing statistical data.

\section{Funding information}

This research received no specific grant from any funding agency in the public, commercial, or not-for-profit sectors.

\section{Data availability statement}

Data sharing is not applicable to this article as no new data were created or analysed in this study.

\section{Disclaimer}

The views and opinions expressed in this article are those of the authors and do not necessarily reflect the official policy or position of any affiliated agency of the authors.

\section{References}

African Honey Bee Database, see AHB Database

AHB Database, 2018a, 'Age and sex distribution', ed. by African Honey Bee.

AHB Database, 2018b, 'Christian survey', ed. by African Honey Bee.

AHB Database, 2018c, 'General', ed. by African Honey Bee.

AHB Database, 2018d, 'Honey', ed. by African Honey Bee.

AHB Database, 2018e, 'Poverty stoplight survey', ed. by African Honey Bee. AHB Database, 2018f, 'Telephone survey December 2018', ed. by African Honey Bee. AHB Database, 2019a, 'Honey value chain', ed. by African Honey Bee. AHB Database, 2019b, 'Productivity survey', ed. by African Honey Bee. AHB Database, 2019c, 'Savings data', ed. by African Honey Bee.

Allsopp, M., 2017, 'The global bee crisis: Fact or fallacy?', paper presented at Apimondia, South Africa.

Android, 2018, Android website, viewed 30 November 2018, from http://www. android.com.

AppSheet, 2018, AppSheet website, viewed 30 November 2018, from http://www. appsheet.com.
Butler, T.C., Brand, C., Draper, C.W. \& Englands, A., 2003, Holman illustrated Bible dictionary, Broadman \& Holman, Nashville, TN.

Buys, P.J., 2013, 'A missional response to poverty and social justice', in S. Logan (ed.), Reformed means missional: Following Jesus in the world, New Growth Press, Greensboro, NC.

Charismatech, 2018, Charismatech website, viewed 07 May 2019, from http://www. charismatech.co.za.

Concise Oxford Dictionary, 2018, 'Evangelical', viewed 07 May 2019, from https:// en.oxforddictionaries.com/definition/evangelical.

De Gruchy, S., 2007, Introducing asset-based community development, viewed 07 May 2019, from http://theologyanddevelopment.ukzn.ac.za/index.php/resources/7mainnav/10-steve-de-gruchy.html.

Douglas, J.D., Bruce, F.F., Packer, J.I., Wiseman, D.J. \& Tasker, R.V.G., 1962, The new Bible dictionary, InterVarsity Fellowship, London.

Fairbourne, J.S., Gibson, S.W. \& Dyer, W.G., 2007, Microfranchising: Creating wealth at the bottom of the pyramid, Edward Elgar Publishing, Cheltenham

Feigenberg, B., Field, E.M. \& Pande, R., 2010, Building social capital through microfinance, National Bureau of Economic Research, Cambridge, MA, USA.

Fisher, J., 2010, Unholy row over World Cup trumpet, BBC Sport, London.

George Whitefield College, 2019, Explore correspondence course, viewed 07 May 2019, from www.gwc.ac.za/explore.

Google Maps, 2018, Google Maps website, viewed 07 May 2019, from http://www. google.com/maps.

Greer, P. \& Smith, P., 2016, Created to flourish, Hope International, Philadelphia, PA.

Hardin, G., 2003, Holman illustrated Bible Dictionary, Thomas Nelson Inc., Nashville, TN.

Haykin, M.A. \& Robinson Sr, C.J., 2014, To the ends of the earth: Calvin's missional vision and legacy, Crossway, Wheaton, IL.

Henry, M., 1991, Commentary on the whole Bible, viewed 07 May 2019, from http:// www.biblestudytools.com/commentaries/matthew-henry-complete.

Hermes, N., 2014, 'Does microfinance affect income inequality?', Applied Economics 46(9), 1021-1034.

Johannsmeier, M., 2001, Beekeeping in South Africa, 3rd rev. edn., ARC-Plant Protection Research Institute, Pretoria.

Kennedy, L., (dir.), 2018, Lawyers, film - Guns \& honey, Netflix, Los Gatos, CA.

Kittel, G., Bromiley, G.W. \& Friedrich, G., 1985, Theological dictionary of the New Testament, vol. 9, Eerdmans, Grand Rapids, MI.

Kretzmann, J. \& McKnight, J., 1993, Building communities from the inside out: A path toward finding and mobilizing a community's assets, 3rd edn., ACTA Publications, Chicago, IL.

Labuschagne, J.K.P., 2009, 'Calvin and mission', HTS Theological Studies 65(1), Art. \#310, 8 pages. https://doi.org/10.4102/hts.v65i1.310

Lange, J.P., Schaff, P., Moll, C.B., Briggs, C.A., Forsyth, J., Hammond, J.B. et al. 2008, A commentary on the holy Scriptures: Psalms, Logos Bible Software, Bellingham, WA.

Lausanne Movement, 2011, The Cape Town commitment: A confession of faith and a call to action 1.7.c, viewed 07 May 2019, from http://www.lausanne.org/content/ call to action 1.7.c, vien
ctc/ctcommitment.

Lehr, D., 2012, Microfranchising at the base of the pyramid, viewed 23 December 2018, from https://static1.squarespace.co.

Lewis, C.S., 2001, Mere christianity, Zondervan, Grand Rapids, MI.

Lorenzo, V., 2010, Settler colonialism: A theoretical overview, John Wiley, Philadelphia, NJ.

Maggay, M.P., 2007, Integral mission: Biblical foundations, Integral Mission, Mumbai.

Mathews, S., 2013, 'Asset-based, community-driven development (ABCD) in South Africa: Rebuilding communities from the inside out', paper presented at University of Johannesburg Centre for Small Business Development Conference, Johannesburg.

Mayne, A.J., 1999, From politics past to politics future: An integrated analysis of current and emergent paradigms, Greenwood Publishing Group, Westport, CT.

McKnight, J. \& Kretzmann, J., 1996, Mapping community capacity (report), rev. edn., Northwestern University Institute for Policy Research, Evanston, IL.

Merrill, E.H., 1994, Deuteronomy, vol. 4, Broadman \& Holman Publishers, Nashville, TN.

Montagu, D., 2002, 'Franchising of health services in low-income countries', Health Policy and Planning, 17(2), 121-130. https://doi.org/10.1093/heapol/17.2.121

Murray, D., 2004, Sermon: - The cause and cure of poverty, viewed 07 May 2019, from https://mp3.sermonaudio.com/download/718048640/718048640.mp3.

Myers, B.L., 2011, Walking with the poor: Principles and practices of transformational development, Orbis Books, New York.

Office of the Municipal Manager: IDP/Development Planning Unit, 2018, Umfolozi integrated development plan, IDP, Umfolozi Municipality.

Peels Honey, 2019, About Peels, viewed 07 May 2019, from https://www.peels. co.za/about-peels/.

Poverty Stoplight SA, 2018, A movement towards poverty eradication in South Africa, viewed 07 May 2019, from http://www.povertystoplight.org.za.

Reformed Church Tshwane, 2016, Catechism Ikhatikizem Katikizem, viewed 07 May 2019, from http://www.africanhoneybee.co.za/pdf/AHB-Catechism-new.pdf. 
Ricketts, K., 2018, Improving livelihoods and forest conservation through beekeeping in northern KwaZulu-Natal, Rhodes University, Grahamstown.

Root, A., 1975, ABC and XYZ of bee culture: An encyclopaedia pertaining to scientific and practical culture of bees, rev. by E.R. Root, H.H. Root \& J.A. Root, Abe books, Victoria, Canada.

Samuel, C.B., 2018, 'Proclamation and demonstration', Micah global triennial consultation, integral mission and resilient communities, organised by Micah Philippines, Tagaytay City.

SaveAct, 2018, SaveAct website, viewed 07 May 2019, from http://saveact.org.za.

Stanley, B., 2013, The global diffusion of evangelicalism: The age of Billy Graham and John Stott, vol. 5, InterVarsity, Westmont, IL.

Stats SA, 2015, General household survey, viewed 07 May 2019, from http://www. statssa.gov.za.

Stats SA, 2017, General household survey, viewed 07 May 2019, from http://www. statssa.gov.za.

Stats SA, 2018, Mfolozi, viewed 07 May 2019, from http://www.statssa.gov. $\mathrm{za} / \mathrm{p}=9922$.
Stubbs, G., 2011, Retention strategy for development beekeepers, Regent University, Virginia Beach, VA.

Trading Economics, 2018, South Africa unemployment rate, viewed 07 May 2019 from https://tradingeconomics.com/south-africa/unemployment-rate.

Tutu, D., 2013, Youtube interview - Who we are: Human uniqueness and the African spirit of Ubuntu, viewed 07 May 2019, from https://youtu.be/OwZtfqZ271w.

uMfolozi Local Municipality, 2016, uMfolozi Local Municipality website, viewed 29 February 2019, from https://umfolozi.gov.za.

Visser, K., 2017, Informal discussion on the timber industry, Timber Industry, Bushbuckridge.

Wolff, R.D. \& Resnick, S.A., 1987, Economics: Marxian versus neoclassical, John Hopkins University Press, Baltimore, MD.

Wright, C., 2015, Five marks of mission: Making God's mission ours, Integral Mission, Mumbai.

Wright, N.T., 2008, Surprised by hope: Rethinking heaven, the resurrection, and the mission of the church, Zondervan, Grand Rapids, MI.

Appendices starts on the next page $\rightarrow$ 


\section{Appendix 1}

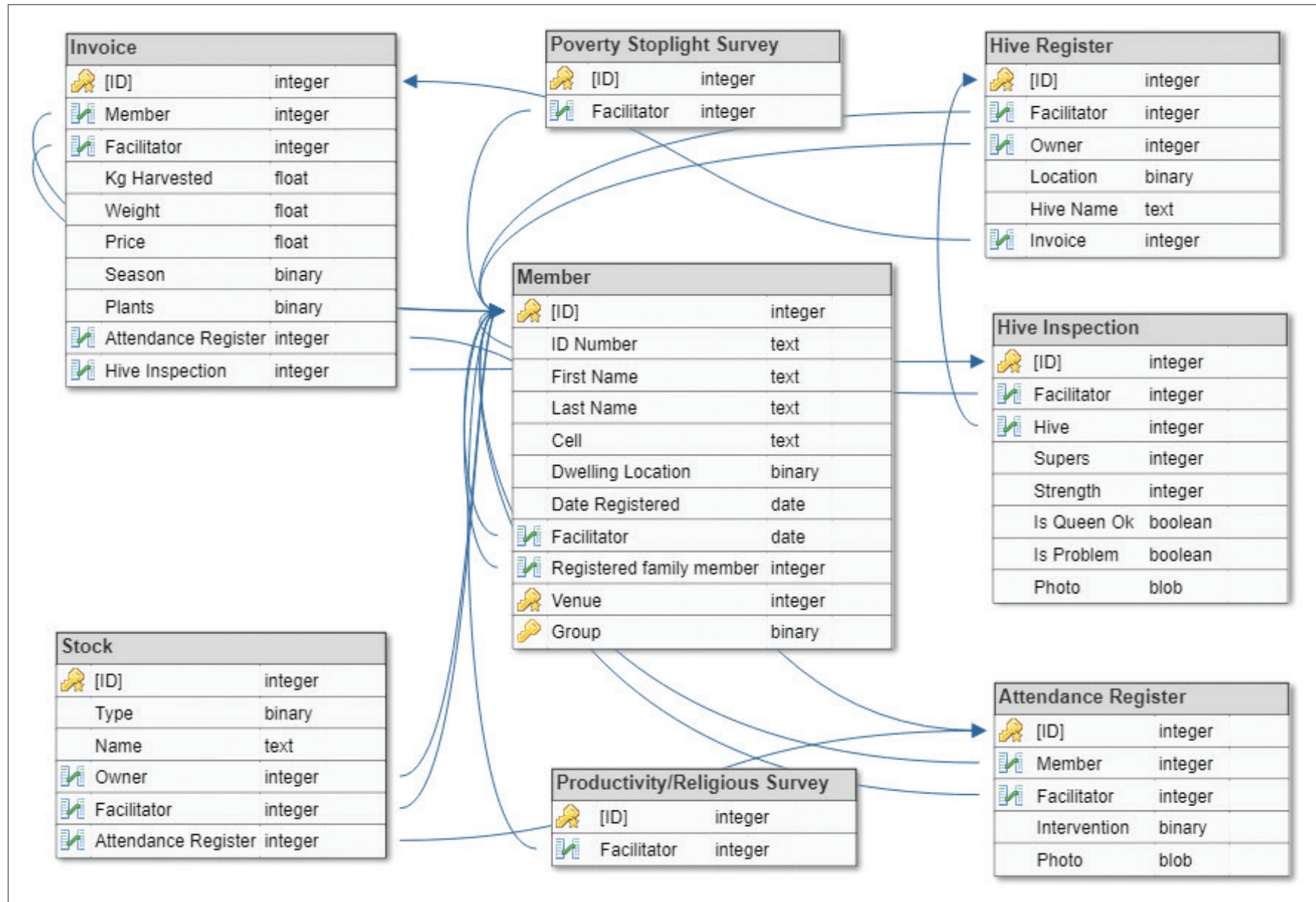

FIGURE 1-A1:The impact app map. 


\section{Appendix 2}

The Impact app map - Poverty stoplight survey poverty stoplight

1. Income/earnings above the poverty line

2. Stable employment and income sources

3. Access to credit facilities

4. Family savings

5. Personal identification (ID books)

6. Access to drinking water

7. Access to quality health care centre

8. Nutrition

9. Personal hygiene

10. Physical health

11. Vaccinations

12. Sexual health and family planning

13. Parenting

14. Garbage disposal

15. Unpolluted environment

16. Alcohol and drugs

17. Legal property rights

18. Home structure

19. Sanitation and sewerage

20. Electricity

21. Refrigerator and household appliances

22. Separate bedrooms

23. Stove and kitchen

24. Basic household standards

25. Regular means of transport

26. Distance and time to work

27. Security

28. Clothing

29. Literacy in English

30. Children enrolled in school until grade 12

31. Access to quality education

32. School transportation, supplies, uniforms and books

33. Knowledge and skills to generate income

34. Capacity to budget and plan

35. Social networks and participation in self-help or support groups

36. Access to information and means to communicate

37. Entertainment and recreation

38. Cultural traditions and heritage

39. Respect for other cultures

40. Awareness of human rights (for children, disabled people, women and the elderly)

41. Influence on the public sector

42. Ability to solve problems and conflicts

43. Registered to vote and votes in elections

44. Awareness of needs: life map and personal goals

45. Self-confidence and self-esteem

46. Moral values and conscience

47. Awareness of own and other people's emotions

48. Appreciation of nature and beauty

49. Violence against vulnerable people

50. Entrepreneurial spirit and motivation

\section{Appendix 3}

The Impact app map - Productivity productivity / religion survey

1. Highest school level

2. Drivers licence

3. Keeping poultry

4. Poultry for meat

5. Poultry for eggs

6. Selling eggs

7. Selling poultry meat

8. Growing vegetables

9. Tower gardening

10. Selling vegetables

11. Growing fruit

12. Selling fruit

13. Growing timber

14. Timber harvest years

15. Selling timber

16. Keeping bees

17. Selling honey

18. Number of hives

19. Number of hives with bees

20. Harvested honey

21. Sold honey to AHB before

22. Buy honey agreement with $A H B$

23. Want to sign Buy honey agreement with AHB

24. Do you have hives with frames

25. Do you use protective clothing when beekeeping

26. Do you use a smoker when beekeeping

27. Do you leave honey for the bees after harvesting

28. Do you use a sterilised food grade bucket when harvesting

29. Do you manage your brood

30. Do you keep apiaries small enough to produce honey

31. Do you keep apiaries in areas where there is food for the bees

32. Do you protect your hives from vandals/thieves

33. Do you protect your hives from fire

34. Do you protect your hives from ants

35. Do you protect your hives from honey badgers

\section{Appendix 4}

The Impact app map - Christian survey

1. What religion are you

2. Name of church

3. Name of pastor

4. Cell number of pastor

5. Do you own your own Bible

6. What language do you prefer for reading the Bible in

7. What do you think of when you hear the name Jesus Christ

8. What is $\sin$

9. Can your sins be forgiven

10. How are your sins forgiven

11. How frequently do you attend church activities (services)

12. How frequently do you pray

13. How often do you read the Bible 


\section{Appendix 5}

The Impact app map - Stock survey stock

1. Flatpack

2. Bibles

3. Catechism

4. Manual

5. Booklet

\section{Appendix 6}

The Impact app map - Interventions survey interventions

1. Level 1

2. Level 2

3. Level 3

4. Saving training

5. Sandwich business

6. Business plan

7. Meat chicken plan

8. Meat chicken brooder

9. Meat chicken hok

10. Meat chicken visit

11. Egg chicken plan

12. Egg chicken hok

13. Egg chicken visit

14. Seedling shelf

15. Tower garden

16. Liquid manure

17. Fruit tree

18. Veggie/Fruit visit

19. Hive visit

20. Buy honey

21. Meeting

22. Savings training

23. Savings meeting

24. Other 